\title{
The Lake Bond deposit: superimposed volcanogenic and synorogenic base and precious metal mineralization in the Robert's Arm Group, central Newfoundland
}

\author{
Karen A. Hudson \\ Geological Survey of Canada, P.O. Box 8700, St. John's, Newfoundland A1B 4J6, Canada
}

and

\author{
H. Scott Swinden \\ Newfoundland Department of Mines and Energy, Geological Survey Branch, P.O. Box 8700, \\ St. John's, Newfoundland AlB 4J6, Canada
}

Date Received June 22, 1989

Date Accepted November 10, 1989

\begin{abstract}
The Lake Bond deposit is hosted by Lower Ordovician volcanic rocks of the Robert's Arm Group. Detailed petrological studies indicate that there are two generations of superimposed alteration and sulphide deposition. The first generation mineralization is pre-kinematic, and is characterized by pyrite and $\mathrm{Cu}-\mathrm{Zn}$ sulphides associated with pervasive chloritization and locally intense quartz-sericite alteration. The second generation mineralization occurs in syn- to post-kinematic veins, and comprises locally auriferous $\mathrm{Cu}-\mathrm{Zn}-\mathrm{Pb}$ sulphides in a dominantly $\mathrm{Ca}-\mathrm{Mg}$-Fe silicate gangue.

First generation mineralization resulted in $5 \mathrm{x}$ to $100 \mathrm{x}$ enrichments in $\mathrm{Cu}, \mathrm{Zn}, \mathrm{Pb}, \mathrm{Au}, \mathrm{As}, \mathrm{Sb}, \mathrm{Cd}$ and $\mathrm{Ba}$, with respect to the probable source basalts. Second generation veins, in contrast, carry $100 x$ to $1000 x$ enrichments in most of these metals (except $\mathrm{Sb}$ and $\mathrm{Ba}$ ), substantial enrichments in $\mathrm{Fe}$ and $\mathrm{Mn},>10 \mathrm{x}$ enrichment in $\mathrm{Ag}$, and a marked increase in the enrichment of $\mathrm{Pb}, \mathrm{Au}$, As and $\mathrm{Ag}$ relative to $\mathrm{Cu}$ and $\mathrm{Zn}$ compared to the first generation mineralization. Sphalerites in second generation veins are enriched in $\mathrm{Cd}, \mathrm{Mn}$ and $\mathrm{Fe}$ relative to first generation sphalerites, parallelling enrichments in the whole rocks. The $\mathrm{Ca}-\mathrm{Mg}$ - $\mathrm{Fe}$ vein silicate assemblage suggests fluid temperatures greater than $200^{\circ} \mathrm{C}$ and possibly greater than $300^{\circ} \mathrm{C}$; abundant calcite in the veins implies that $\mathrm{CO}_{2}$ may have influenced mineralization. Fluid inclusions in second generation sphalerite yield average homogenization temperatures of about $306^{\circ} \mathrm{C}$.

The timing of deformation and second generation mineralization in the Lake Bond deposit is constrained to the early Silurian by cross-cutting relationships with dated post-tectonic plutons. Comparisons with other deposits in the Robert's Arm Group and deposits elsewhere incentral Newfoundland suggest a two-stage metallogenic model comprising: (1) an early volcanogenic event coeval with the Lower Ordovician host rocks; and (2) early Silurian hydrothermal activity related to shearing and movement on major faults. The latter is tentatively correlated with a widespread lode gold mineralizing event in central Newfoundland. The second generation auriferous mineralization apparently preferentially overprinted early sulphide zones at Lake Bond suggesting an exploration potential for auriferous zones within low-grade volcanogenic sulphide stockworks in the Buchans-Robert's Arm Belt.
\end{abstract}

Le gîte de Lake Bond est encaissé dans les volcanites du Groupe de Robert's Arm (Ordovicien inférieur). Des études pétrologiques détaillées mettent en évidence deux générations au sein desquelles une altération se superpose au dépôt des sulfures. La minéralisation de première génération est précinématique et se caractérise par de la pyrite et des sulfures de $\mathrm{Cu}-\mathrm{Zn}$ associés à une chloritisation pénétrante ainsi qu'à une altération à quartz et séricite localement intense. La minéralisation de seconde génération se développe dans des veines syn- à postcinématiques et comprend des sulfures à $\mathrm{Cu}-\mathrm{Zn}-\mathrm{Pb}$ localement auriferes à l'intérieur d'une gangue silicatée à dominante $\mathrm{Ca}-\mathrm{Fe}-\mathrm{Mg}$.

La minéralisation de première génération engendra un enrichissement de 5 à 100 fois en $\mathrm{Cu}, \mathrm{Zn}, \mathrm{Pb}, \mathrm{Au}, \mathrm{As}, \mathrm{Sb}, \mathrm{Cd}$ et $\mathrm{Ba}$ par rapport aux basaltes dont elle est probablement issue. En revanche, les veines de seconde génération présentent un enrichissement de 100 à 1000 fois pour la plupart de ces métaux (hormis $\mathrm{Sb}$ et $\mathrm{Ba}$ ), un enrichissement substantiel en $\mathrm{Fe}$ et $\mathrm{Mn}$, un enrichissement supérieur à 10 fois en Ag, ainsi qu'un accroissement marqué de l'enrichissement en $\mathrm{Pb}, \mathrm{Au}, \mathrm{As}$ et $\mathrm{Ag}$ au regard de $\mathrm{Cu}$ et $\mathrm{Zn}$ par rapport à la minéralisation de première génération. En comparaison des blendes de première génération, les blendes localisées dans les veines de second génération sont enrichies en $\mathrm{Cd}, \mathrm{Mn}$, Fe d'une façon comparable à l'enrichissement de la roche totale. $\mathrm{L}$ 'assemblage silicaté à $\mathrm{Ca}$ - $\mathrm{Fe}-\mathrm{Mg}$ des veines suggère une température des fluides supérieure à $200^{\circ} \mathrm{C}$ et peut- 
être dépassant les $300^{\circ} \mathrm{C}$; l'abondance de calcite dans ces veines suggère une influence du $\mathrm{CO}_{2}$ sur la minéralisation. Les inclusions fluides dans la blende de seconde génération livrent des températures moyennes d'homogénéisation autour de $306^{\circ} \mathrm{C}$.

Le recoupement par des plutons post-cinématiques dont l'âge est connu permet de cantonner la déformation et la minéralisation de seconde génération dans le gîte de Lake Bond au début du Silurien. Une comparaison avec les autres gîtes présents dans le Groupe de Robert's Arm ainsi qu'avec des gîtes situés en d'autres points du centre de Terre-Neuve suggère un modèle métallogénique en deux étapes qui sont: (1) un épisode volcanogène précoce contemporain des roches encaissantes ordoviciennes inférieures et (2) un hydrothermalisme éosilurien en liaison avec un cisaillement et un déplacement le long de failles majeures. On corrèle provisoirement cet hydrothermalisme avec un épisode répandu de minéralisation filonienne en or dans le centre de Terre-Neuve. Il semble qu'à Lake Bond, la minéralisation aurifere de seconde génération se soit superposée aux zones de sulfures précoces, ce qui suggère un potentiel d'exploration pour les zones auriferes au sein des stockwerks de sulfures volcanogènes à faible teneur dans la ceinture de Buchans-Robert's Arm.

[Traduit par le joumal]

\section{INTRODUCTION}

The Lake Bond deposit is a Cu-Zn deposit hosted by mafic volcanic rocks of the Lower Ordovician Robert's Arm Group in central Newfoundland (Fig. 1). Discovered in 1955 by New Jersey Zinc Corporation geologists, the deposit was explored sporadically through the 1960's and early 1970's. Published estimates suggest that it contains approximately 1.1 million tonnes grading $0.3 \% \mathrm{Cu}$ and $2.1 \% \mathrm{Zn}$ (Consolidated Morrison Explorations Limited, 1977). The Lake Bond deposit is along strike with and approximately $16 \mathrm{~km}$ to the south of the Gullbridge Mine, which produced 3 million tonnes grading $1.1 \% \mathrm{Cu}$ between 1967 and 1971 (Upadhyay and Smitheringale, 1972; Swinden, 1988).
The Robert's Arm Group in the Lake Bond area is part of a regionally extensive sequence of Lower Ordovician marine volcanic and epiclastic rocks, which locally is referred to as the "Buchans-Robert's Arm belt." In addition to the Gullbridge deposit, this belt contains several other well known volcanogenic massive sulphide (VMS) deposits (Fig. 1), including the Buchans deposits, which produced more than 17 million tonnes of polymetallic base and precious metal ore over a mining life of more than 50 years (Swanson et al., 1981; Kirkham, 1987), and the Pilley's Island deposits in the north, which produced $\mathrm{Cu}$ and sulphur at the turn of the century and are still being actively explored for base and precious metals (Tuach, 1988a).

The southern part of the Robert's Arm Group (hereafter termed "SRAG") hosts numerous small, dominantly $\mathrm{Cu} \pm \mathrm{Zn}$,

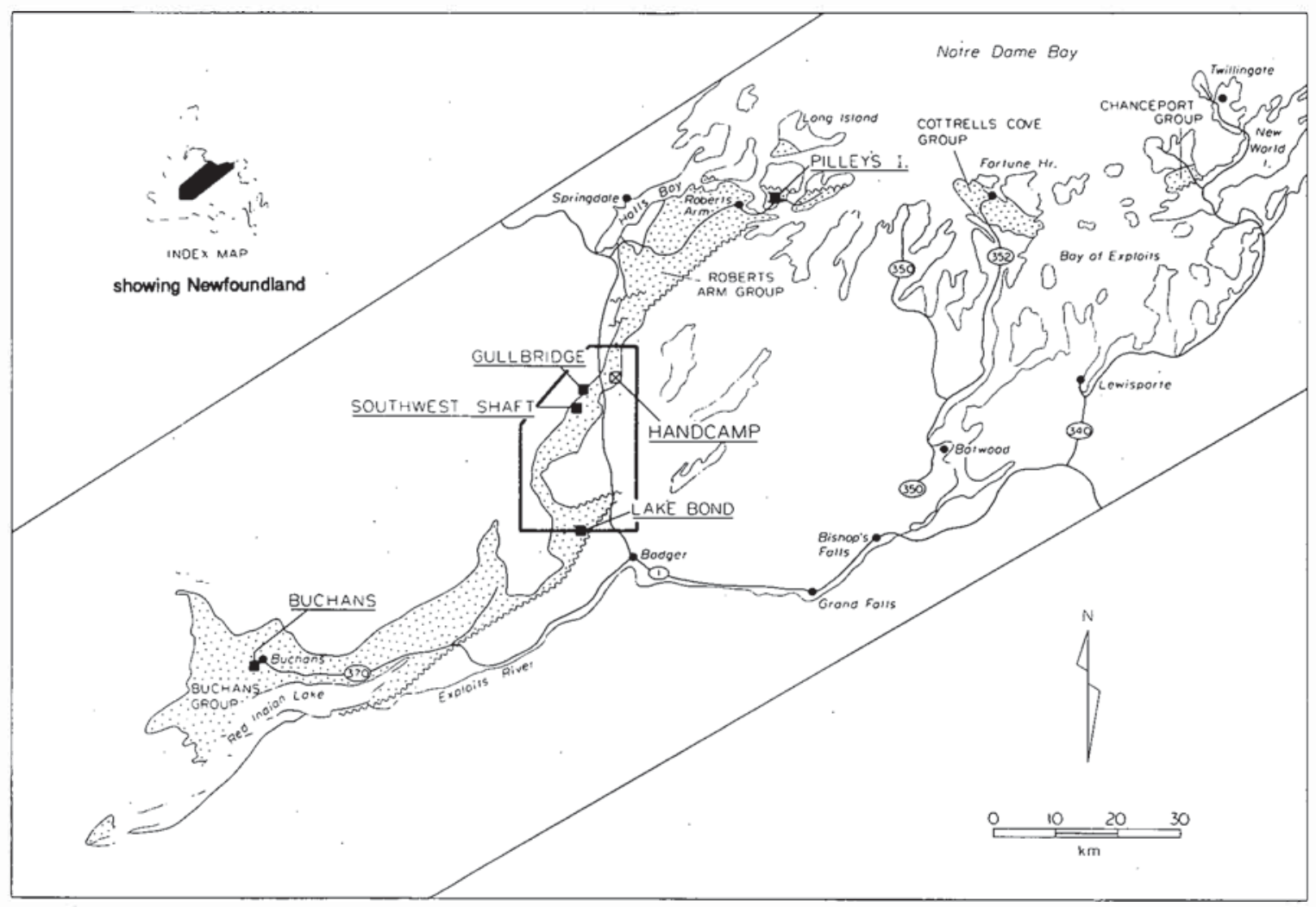

Fig. 1. Location of the Buchans-Robert's Arm belt (stippled) and the southern part of the Robert's Arm Group(SRAG: outlined). Major volcanogenic sulphide deposits are indicated by filled squares, the Handcamp prospect by an open square. 
occurrences in addition to the Lake Bond and Gullbridge deposits (Fig. 2). By analogy with the larger deposits nearby, these generally have been interpreted as volcanogenic (Upadhyay and Smitheringale, 1972; Swinden and Kean, 1984; Swinden and Sacks, 1986; Swinden, 1988). However, an alternative interpretation for one of these deposits was raised by Hudson and Swinden (1989). They suggested, based on petrological, mineralogical and structural evidence, that the Handcamp prospect (Fig. 2) occupies a syn- to post-tectonic, shear-hosted setting, thereby indicating the presence of at least two regionally important mineralizing events in the Buchans-Robert's Arm belt, rather than the one volcanogenic event previously recognized.

In this paper, we present petrological, geochemical and fluid inclusion data from the Lake Bond deposit in support of the suggestion that this syn- to post-tectonic alteration and mineralization event is widespread in the SRAG and locally overprints the earlier pre-tectonic, probably volcanogenic, mineralization.

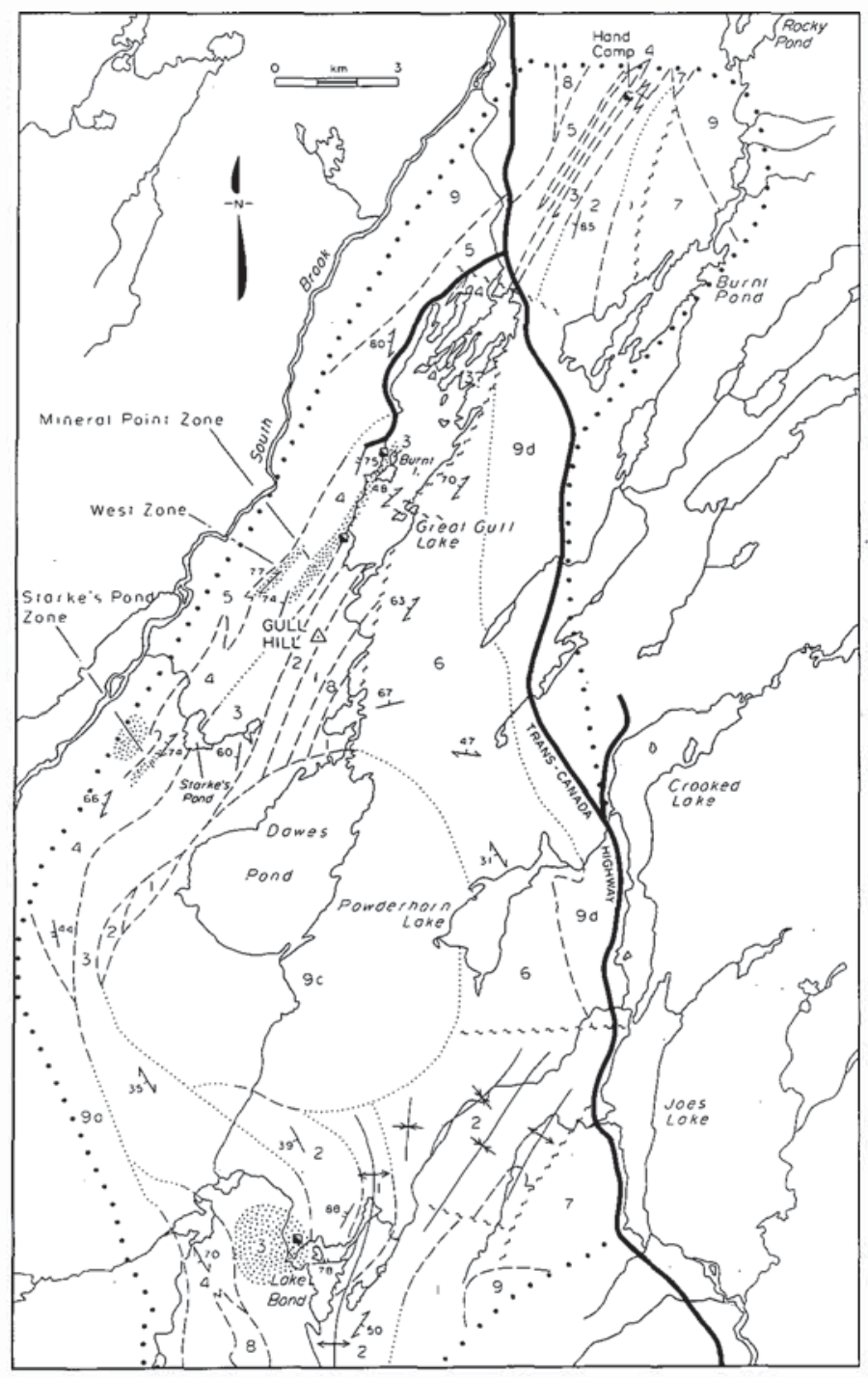

Because this second stage mineralization is locally auriferous, its recognition implies an enhanced exploration potential for sulphide showings in the SRAG, previously thought to have potential only for low-grade base metals.

\section{REGIONAL GEOLOGY}

The SRAG consists mainly of mafic volcanic rocks (dominantly pillow lavas, locally massive flows and tuffs) with lesser felsic volcanic and epiclastic sedimentary rocks. To the west, the SRAG is overlain uncomformably by unnamed Carboniferous red sedimentary rocks and by Silurian subaerial felsic volcanic rocks of the Springdale Group, and intruded by the Silurian Skull Hill alkali intrusive suite. To the east, the SRAG is intruded by the post-tectonic Twin Lakes granodiorite and Dawes Pond Granite.

Swinden and Sacks (1986) recognized a west-facing lithol-

\section{Legend}

\section{DEVONIAN AND YOUNGER}

9 Granitoid intrusive rocks; 9a - Skull Hill Quartz Syenite; 9c - Dawes Pond granite; 9d - Twin Lakes Complex

8 Mafic and ultramafic plutonic rocks; gabbro, diorite, diabase, pyroxenite

\section{ORDOVICIAN-SILURIAN}

7 Sansom Greywacke; volcaniclastic sandstone turbidites, pebble conglomerates

6 Thermally metamorphosed and deformed quartzite, andalusite - and staurolite - bearing pelite, carbonaceous pelite

\section{LOWER ORDOVICIAN}

\section{ROBERT'S ARM GROUP}

5 South Brook basalt*; pillow lava, massive basalt

4 Gullbridge felsic volcanics*; rhyolitic ash flow tuff, rhyolite flows, minor chloritic schist

3 Burnt Island basalt*; pillow lava, mafic tuff, chloritic schist

2 Gull Hill sedimentary rocks*; volcaniclastic chert, ferruginous chert, silicic siltstone, sandstone

1 Baker Brook basalt*; pillow lava, massive basalt

*informal name

Fig. 2. General geology of the southem part of the Robert's Arm Group (after Swinden and Sacks, 1986). Alteration zones are stippled. Contacts are probably mainly structural. Principal sulphide deposits are indicated by half-closed squares. The Lake Bond deposit is exposed in several trenches near the northeast comer of Lake Bond; stipple in this area represents the extent of second generation epidote alteration. Volcanogenic sulphide deposits on the west side of Great Gull Lake are the Gullbridge (north) and Southwest Shaft (south). 
ogical succession in the SRAG which they tentatively suggested was also litho-stratigraphic. They identified five informal lithological units from east to west: the Baker Brook basalt, Gull Hill sediments, Burnt Island basalt, Gullbridge felsic volcanics and South Brook basalt (Fig. 2). Our subsequent mapping and geochemical studies suggest that this lithological succession is structurally more complex than was recognized by Swinden and Sacks (1986). Contacts between units are locally structural and there is extensive evidence for shearing and faulting in the area. Furthermore, preliminary geochemical data for the volcanic rocks suggest that some lithological units are composite (H.S. Swinden, unpublished data). Despite this, these units present a convenient framework for discussion of the general geology, and are retained in the present discussion.

The entire SRAG is structurally attenuated, deformed, and metamorphosed in the greenschist facies, producing a spilitic assemblage of albite-actinolite-chlorite-epidote-sphene in the mafic volcanic rocks. The rocks are polydeformed and carry a prominent, northeast-trending schistosity which is also known to have affected fossiliferous Lower Silurian Sansom Greywacke in the Robert's Arm area to the north (Dean and Strong, 1976). A post-main schistosity thermal metamorphic overprint, probably related to the intrusion of the post-tectonic Twin Lakes granodiorite, affected much of the SRAG and the adjacent Sansom Greywacke, resulting in growth of andalusite \pm garnet \pm staurolite in pelitic rocks and a distinctive cordierite-anthophyllite \pm andalusite assemblage in mineralized alteration zones at and near the Gullbridge deposit.

\section{THE LAKE BOND DEPOSIT}

\section{Geological setting and petrography}

The Lake Bond deposit, hosted by highly altered pillow lavas assigned to the Burnt Island basalt, is exposed in a series of trenches on the northwest shore of Lake Bond (Swinden, 1988) (Fig. 2). The deposit was extensively drilled in the 1960's and 1970 's and core dumps and boxes of core remain at the site and preserve intersections representing the mineralized zone.

Rocks in the mineralized zone are pervasively chloritized and locally silicified; sulphides comprise disseminations, stringers, veinlets and small massive pods of pyrite, sphalerite, lesser chalcopyrite and, locally, minor galena. The deposit is particularly zinc-rich relative to other deposits in the SRAG. Epidote alteration, though not common in the immediate ore zone, is widespread over an area of $2 \mathrm{~km}^{2}$ around the deposit (Fig. 2), and locally is accompanied by minor pyrite \pm chalcopyrite.

Although generally interpreted to be a large volcanogenic stockwork zone on the basis of the geological setting and the sulphide and alteration mineralogy (Consolidated Morrison Explorations, 1977; Swinden and Sacks, 1986; Swinden, 1988), petrographic observations suggest a more complex mineralization history. Observations of thin and polished sections indicate that alteration and sulphide minerals are of two generations which can be separated on the basis of mineralogy and the relationships to the main deformation:

(1) deformed sphalerite and pyrite with lesser chalcopyrite occur as disseminations, stringers and pods associated with a pervasive chloritization and local silicification of the host basalts. The altered basalts contain a marked penetrative foliation, defined by aligned, 1 to $4 \mathrm{~mm}$ thick, wispy chlorite and sphalerite, as well as minor sphene and in some cases, sericite. Chlorite-and calcite-filled vesicles in altered basalts are flattened parallel to the foliation. Pyrite crystals are enveloped by quartz pressure shadows, and indicate dextral rotation. The sulphides frequently are brecciated and/or boudinaged, with fragments aligned parallel to the schistosity. This alteration/sulphide assemblage clearly is pre-tectonic and hereafter is termed the "first generation" mineralization.

(2) sphalerite, chalcopyrite, pyrite and trace galena occur in veins ranging from $1 \mathrm{~mm}$ to $>1 \mathrm{~cm}$ wide, which cut the dominant foliation. Many vein-hosted sphalerite grains show traces of growth zoning, suggesting that they were not affected by deformation. Although commonly undeformed, some of the veins have sheared edges, with accompanying fragmentation and shearing of the sulphides parallel to the first schistosity, suggesting that they are partly syn-kinematic. Chalcopyrite grains are rounded to subangular, and generally are enclosed by sphalerite. Galena occurs as fine disseminations in the veins. This mineralization, which is clearly later than the deformed sulphides described above, is hereafter termed "second generation" mineralization.

Major gangue constituents in the second generation veins include epidote occurring as radial aggregates of rectangular crystals, and second generation calcite, quartz and blue, birefringent chlorite. Veins containing calcite, quartz and chlorite typically are strongly banded, with the calcite cleavages forming "V" shapes about the banding direction, suggesting that they were syn-kinematic minerals. Minor gangue constituents include blocky and rectangular clinozoisite, and zoned, euhedral, brown-black garnet (possibly grossular or andradite).

The contrasting parageneses of first and second generation mineralization are summarized in Figure 3.

\section{Geochemistry}

\section{Analytical methods}

Eighteen whole rock samples taken from trenches and drill core at the Lake Bond deposit, representing both first and second generation mineralization, were analyzed for major and trace elements at X-Ray Assay Laboratories, Don Mills, Ontario, in an effort to characterize the two mineralizing episodes geochemically. Major element analyses were carried out by X-ray fluorescence. Instrumental precision is quoted by the analysts as better than $0.5 \%$ and this was confirmed by analysis of blind duplicate samples. Trace elements were analyzed as follows (detection limits in brackets): $\mathrm{Cd}(1 \mathrm{ppm}), \mathrm{Co}(1 \mathrm{ppm}), \mathrm{Pb}(2 \mathrm{ppm}), \mathrm{Ni}$ (1 $\mathrm{ppm}), \mathrm{Ag}(0.5 \mathrm{ppm}), \mathrm{Cr}(2 \mathrm{ppm})$, and $\mathrm{V}(2 \mathrm{ppm})$ by direct-current plasma spectrometry; As ( $0.1 \mathrm{ppm})$ and $\mathrm{Sb}(0.1 \mathrm{ppm})$ by flameless atomic absorption spectrometry; and $\mathrm{Au}(1 \mathrm{ppb})$ by fire assay-neutron activation. Precisions for all trace elements are quoted by the analysts as $\pm 20 \%$ at $10 \times$ detection limit (d.I.), $\pm 10 \%$ at $100 \times$ d.l., and $\pm 5 \%$ at $>100 \times$ d.l. $\mathrm{Cu}$ and $\mathrm{Zn}$ were 


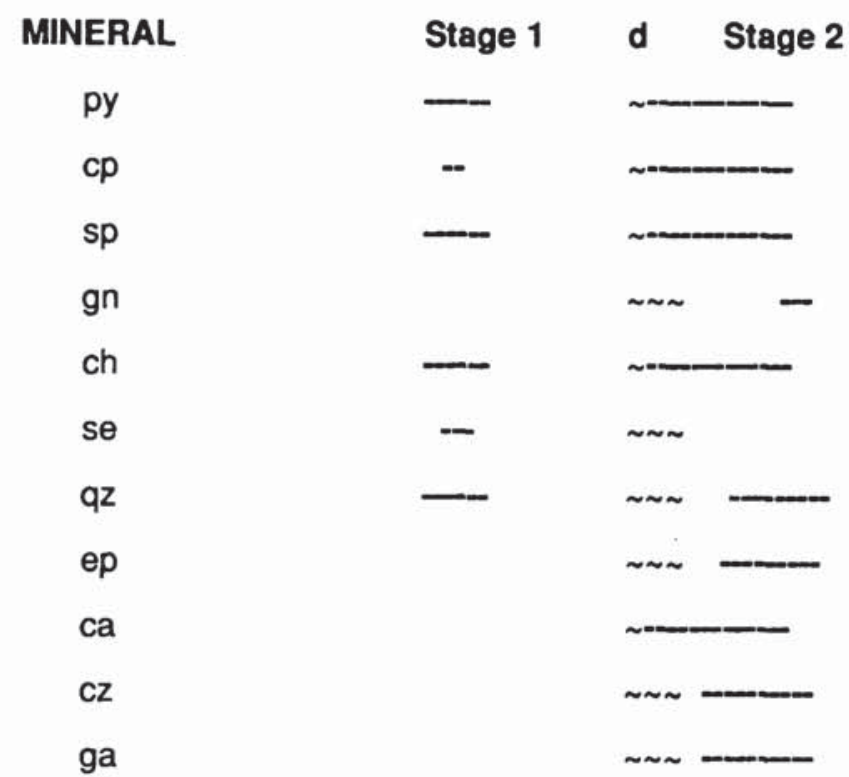

Fig. 3. Paragenesis of hydrothermal minerals at Lake Bond. Pyrite, sphalerite, chlorite, quartz and minor chalcopyrite were deposited during the first generation of mineralization, and were subsequently deformed. Second generation mineralization began during the last stages of the deformational event, and continued beyond it, forming sulphidecalc-silicate veins. Symbols: $d=$ deformation; py $=$ pyrite; $c p=$ chalcopyrite; $\mathrm{sp}=$ sphalerite; $\mathrm{gn}=$ galena; $\mathrm{ch}=$ chlorite; $\mathrm{se}=$ sericite; $\mathrm{qz}$ = quartz; $\mathrm{ep}=$ epidote; $\mathrm{ca}=$ calcite; $\mathrm{cz}=$ clinozoisite; $\mathrm{ga}=$ garnet .

analysed by Atomic Absorption Spectrophotometry at the Newfoundland Department of Mines and Energy laboratory. Precision is better than $\pm 5 \%$ at the concentrations present.

\section{Results}

In none of the samples was it possible to completely separate second generation from first generation mineralization, as both are pervasively developed. In attempting to geochemically characterize the two mineralization types, samples were chosen in which one or the other generation of mineralization was seen in hand specimen and/or thin section to be predominant. Samples which lacked undeformed sulphides and $\mathrm{Ca}-\mathrm{Fe}-\mathrm{Mg}$ silicate veins were considered to represent first generation mineralization whereas samples with abundant undeformed alteration silicates and sulphides were considered to represent second generation mineralization.

Element enrichments in the Lake Bond deposit resulting from alteration and mineralization were calculated according to the method of Grant (1986), who simplified Gresens' (1967) equation for changes in volume and concentration during metasomatism. Hydrothermally altered rocks were compared to unaltered equivalents by plotting altered versus unaltered rock for all components. An 'ISOCON', a reference line corresponding to a zero concentration change (essentially passing through all immobile components) was chosen, and relative gains and losses of mobile components were calculated using the displacements of their corresponding data points from the reference isocon. For this study, altered rocks were compared to relatively unaltered equivalents by basing the slope of the isocon on constant (or immobile) $\mathrm{TiO}_{2}$, given by the equation:

$$
\left(\mathrm{dCA} / \mathrm{Ci}_{0}\right)=\left(\mathrm{C}_{0}^{\mathrm{TiO}_{2}} / \mathrm{CA}^{\mathrm{TiO}_{2}}\right)\left(\mathrm{CA}_{/} / \mathrm{Ci}_{\sigma}\right)-1
$$

where $\mathrm{dCA} / \mathrm{Ci}$ o change (gain or loss) in concentration of a component relative to an unaltered equivalent (a dimensionless variable known as the 'enrichment factor'); $i$ = subscript for the component; $\mathrm{Co}=$ reference concentration of the component for relatively unaltered sample; $\mathrm{CA}=$ concentration of component for altered sample.

The unaltered sample chosen for the Lake Bond calculations was a basalt (85SS82-Table 1) from the Burnt Island map unit in the immediate vicinity of the trenches. The rock consists of nearequal proportions of clinopyroxene and plagioclase, with minor epidote, sphene and chlorite. Its composition is representative of other Burnt Island basalt samples in the area and constitutes a best estimate of the composition of the volcanic rocks in the footwall of the deposit (i.e., the principal metal source for volcanogenic mineralization). Geochemical enrichments/depletions of mineralized samples relative to this reference basalt are illustrated in Figure 4.

First generation mineralization is slightly enriched in $\mathrm{FeOt}$ and $\mathrm{MnO}$, and depleted in $\mathrm{CaO}$ relative to the reference basalt. This is consistent with petrographic observations that pervasive quartz-chlorite alteration is early, and completely replaces primary minerals. Although silicification is a common alteration effect in first generation mineralization, the analytical results indicate that this did not result from net addition of silica to the rock but probably from reprecipitation of silica released by the breakdown of silicate minerals during chlorite-forming reactions. Second generation mineralization also is enriched in $\mathrm{FeO} t$ and $\mathrm{MnO}$, but to a much greater extent, reflecting significant quantities of $\mathrm{Fe}$ - and $\mathrm{Mn}$-rich sphalerite in the second generation veins. The apparent conservation of $\mathrm{CaO}$ in second generation mineralization reflects the abundance of Ca-rich minerals and suggests that $\mathrm{CaO}$ lost through first generation mineralizing processes may have been regained through addition of new $\mathrm{Ca}$ during second generation mineralization.

Samples representing the first generation mineralization show a minor average enrichment in $\mathrm{FeOt}$ and $\mathrm{MnO}$ ( $2 x$ to $4 \mathrm{x}$ ), and a somewhat greater average enrichment of about $250 \mathrm{x} \mathrm{Zn}$, $10 \mathrm{x}$ to $40 \mathrm{x}$ in $\mathrm{Cu}, \mathrm{Pb}, \mathrm{Au}$ and $\mathrm{Cd}$, and $4 \mathrm{x}$ to $5 \mathrm{x} \mathrm{As}, \mathrm{Sb}, \mathrm{Ba}$ and Mo with respect to the reference basalt (Fig. 4). There is no relative enrichment in Ag.

Enrichment factors for second generation mineralization, in contrast, show a considerably more substantial enrichment in $\mathrm{FeOt}$ and $\mathrm{MnO}$, and in all metals, with $\mathrm{Cu}, \mathrm{Zn}, \mathrm{Pb}$, and $\mathrm{Au}$ enriched between $500 x$ and $3000 x$, As and $C d$ enriched $>200 x$, and $\mathrm{Ag}$ and $\mathrm{Sb}$ enriched approximately $20 \mathrm{x}$ to $200 \mathrm{x}$ respectively over the reference Burnt Island basalt (Fig. 4). Although no oregrade Au samples were analyzed during this study, individual grab samples carry up to $470 \mathrm{ppb} \mathrm{Au}$ (Table 1). It should be noted that the apparent Mo enrichment in each generation of mineralization results from single anomalous samples (Table 1) and there is no consistent enrichment pattern for this element in either generation. 


\begin{tabular}{|c|c|c|c|c|c|c|}
\hline 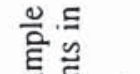 & $\stackrel{\circ}{\Sigma}$ & $n-n N N-n-n M n \rightarrow n$ & $n-$ & nOntan & $m N$ & $N$ \\
\hline 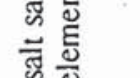 & 己 & 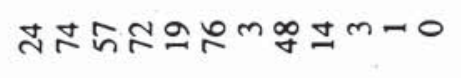 & लెल & 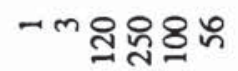 & $\infty$ & - \\
\hline $\begin{array}{l}0 \\
0 \\
0 \\
0\end{array}$ & के & 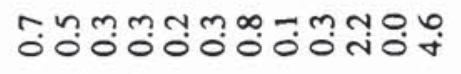 & -- & تơं & $\rightarrow n$ & กั \\
\hline 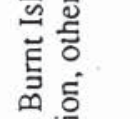 & \& & 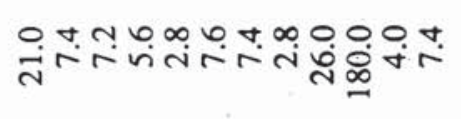 & ก̊ & 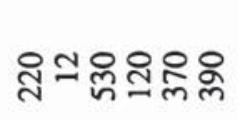 & 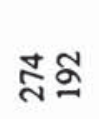 & 0 \\
\hline & z & n-n-ーnกรด & $\simeq \simeq$ & 느뉴워응워 & ర્તڤ & - \\
\hline 童 & $<$ & 000000000000 & 00 & oor ynn & $n n$ & $\tilde{0}$ \\
\hline 定. & 2. & 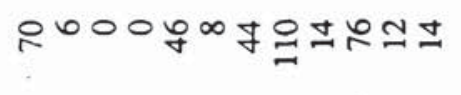 & mల్ల & 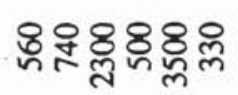 & స్త్రీ్తి & $N$ \\
\hline 宊芯 & งิ & 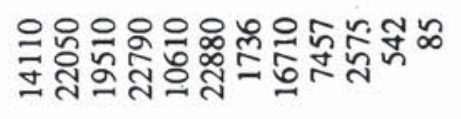 & 乞̊: & 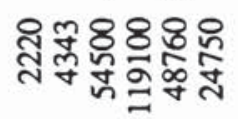 & 守志 & $\tilde{n}$ \\
\hline 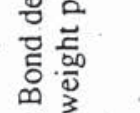 & 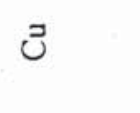 & 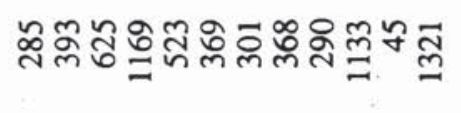 & ดेำ & 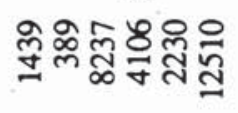 & 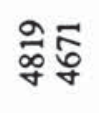 & 茫 \\
\hline 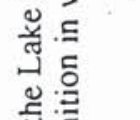 & $\underset{0}{0}$ & 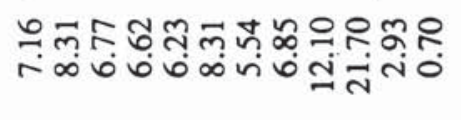 & 춖ำ & 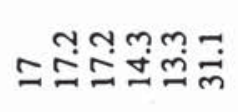 & œై & $\underset{\sim}{\sim}$ \\
\hline 施 & ర్లు & 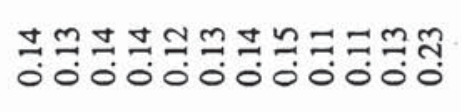 & $\stackrel{ \pm 0}{0}$ & 응ํํ융ㅇํㅇ & 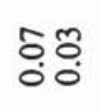 & $\stackrel{7}{\circ}$ \\
\hline 츈을 & 号 & 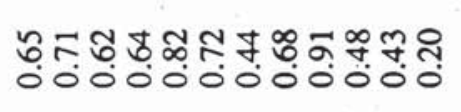 & 뭉 & 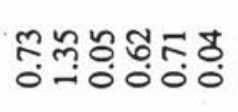 & ڤొర & đั \\
\hline 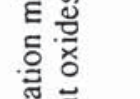 & $\stackrel{\mathcal{O}}{\mathscr{H}}$ & 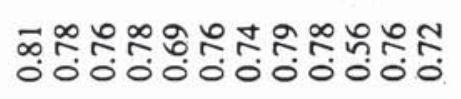 & 色家 & 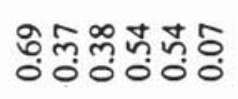 & 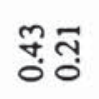 & ळे \\
\hline 岕 & ○్ల & 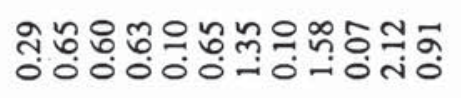 & $\stackrel{n}{\check{0}}$ & 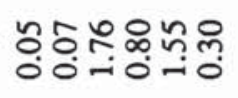 & $\stackrel{n}{i} \frac{n}{0}$ & $\stackrel{n}{\sim}$ \\
\hline 递要 & $\underset{\text { Z }}{\text { Z }}$ & 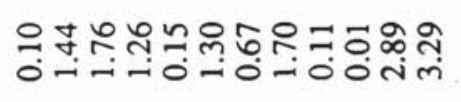 & సุํํ.- & 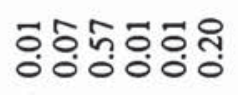 & $\frac{n}{0}$ & $\stackrel{\infty}{\longleftarrow}$ \\
\hline $\begin{array}{l}3 \\
5 \\
0 \\
0 \\
0\end{array}$ & ర్ల & 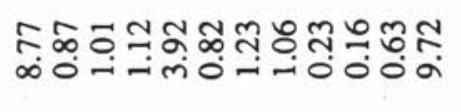 & ণ̛̣m & 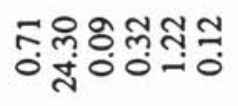 & +̛̣ & 음 \\
\hline 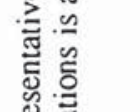 & $\sum_{i}^{\circ}$ & 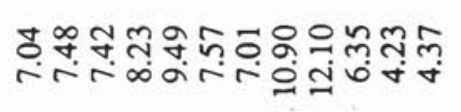 & 윢 & 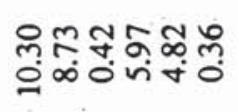 & $\stackrel{9}{\stackrel{7}{*}}$ & $\stackrel{8}{\circ}$ \\
\hline 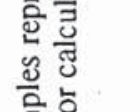 & ö & 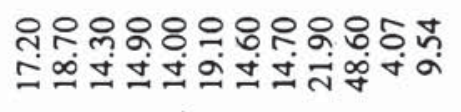 & m̊: & 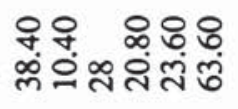 & @ & $\stackrel{0}{0}$ \\
\hline 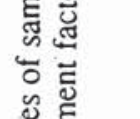 & $\frac{\text { O্}}{\mathbb{K}}$ & 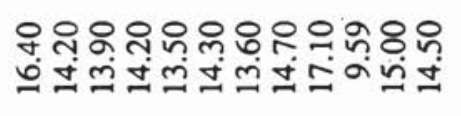 & 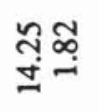 & 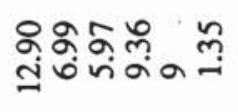 & 官 & $\stackrel{8}{\mathscr{8}}$ \\
\hline 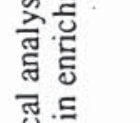 & 旅 & 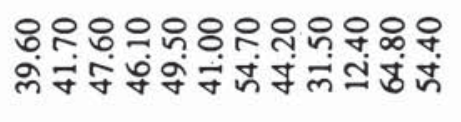 & 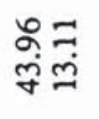 & 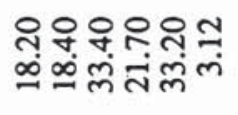 & 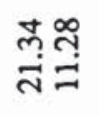 & $\begin{array}{l}\stackrel{8}{\infty} \\
\text { ণ }\end{array}$ \\
\hline 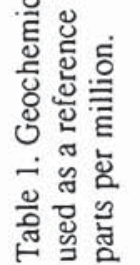 & 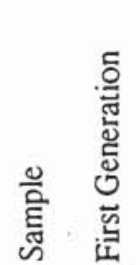 & 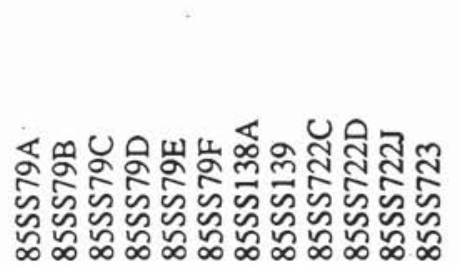 & 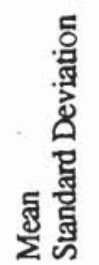 & 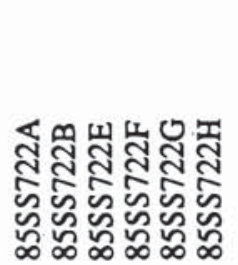 & 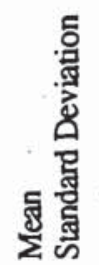 & 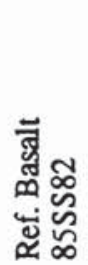 \\
\hline
\end{tabular}



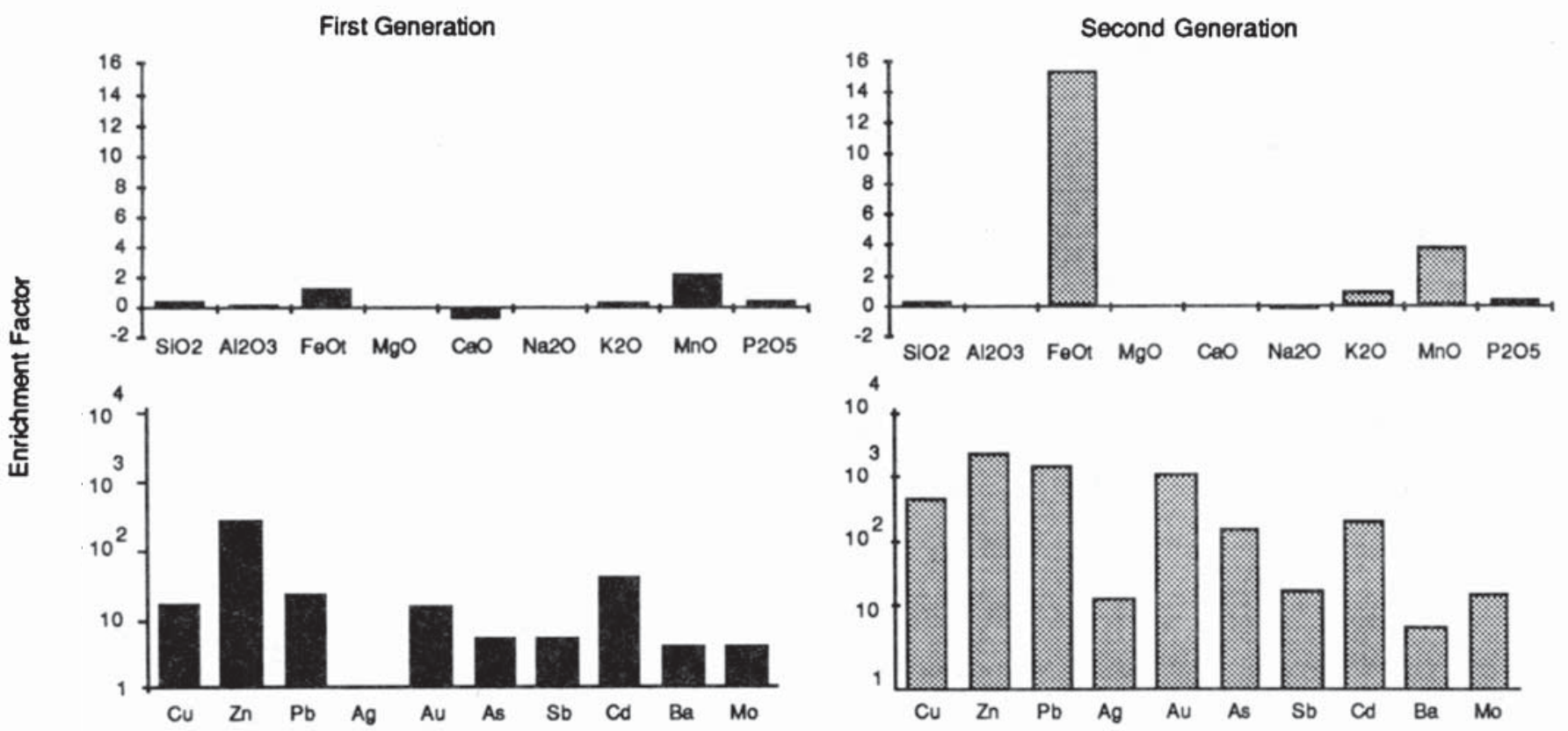

Fig. 4. Illustration of metasomatic enrichment/depletion of first and second generation alteration and mineralization at the Lake Bond deposit with respect to unaltered Bumt Island basalt (Table 1). See text for description of calculation. First generation, dominantly Cu- $\mathrm{Zn}$, mineralization has resulted in slight to moderate enrichments of $\mathrm{FeO}, \mathrm{MnO}$ and most metals (except $\mathrm{Ag}$ ). Second generation mineralization has produced substantially greater absolute enrichments of $\mathrm{FeO}, \mathrm{MnO}$ and all metals (including $\mathrm{Ag}$ ). Note, particularly, that in the second generation event, $\mathrm{Pb}$ and $\mathrm{Au}$ are enriched as much as $\mathrm{Zn}$ (in contrast to first generation) and that As is substantially enriched with respect to Sb.

The contrast in metal enrichment patterns is further illustrated in Figure 5, which emphasizes the enrichment of the various metals in each generation relative to total $\mathrm{Cu}$ and $\mathrm{Zn}$ enrichment. The second generation mineralization is characterized by substantially greater enrichments of $\mathrm{Pb}, \mathrm{Au}, \mathrm{Ag}$ and $\mathrm{As}$ relative to $\mathrm{Cu}$ and $\mathrm{Zn}$ than the first generation mineralization. Enrichments in $\mathrm{Sb}$ and $\mathrm{Cd}$ were approximately the same or slightly less than in the first generation event. The substantially greater enrichments of these metals relative to $\mathrm{Cu}+\mathrm{Zn}$ provides a distinctive geochemical fingerprint of the second generation alteration and mineralization and suggests contrasts in either metal sources, fluid histories or depositional processes in the two generations of mineralization.

\section{Sphalerite chemistry}

\section{Analytical methods}

Sixteen sphalerite grains were analyzed with a Materials Analyses Company Model 400 electron microprobe at the Geological Survey of Canada. On-line computer software calculated mineral formulae and molecular proportions of the chemical constituents. The analyses are in Table 2 and inter-element relationships illustrated in Figure 6.

\section{Results}

The data show that the petrographic and chemical distinction of first and second generation alteration and mineralization are

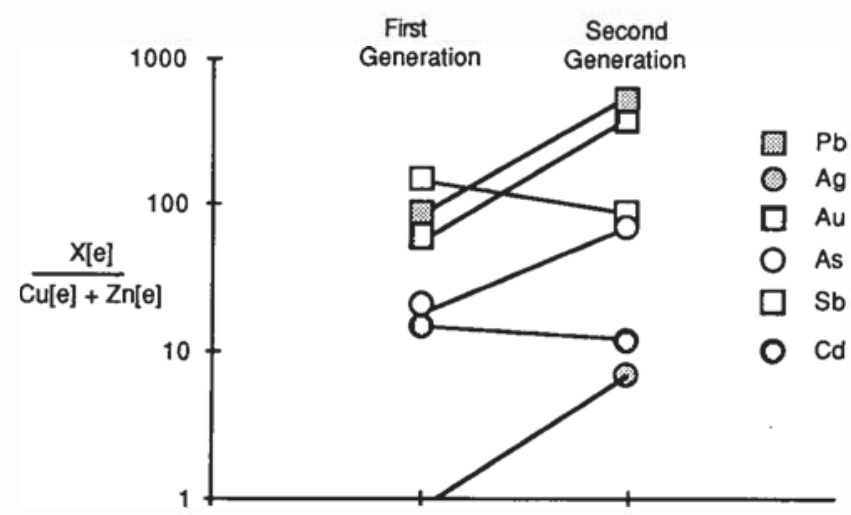

Fig. 5. Relative enrichment of selected metals with respect to $\mathrm{Cu}+\mathrm{Zn}$ in first and second generation mineralization. " $x[e] "$ is the enrichment factor for the various metals shown in the legend, $\mathrm{Cu}[\mathrm{e}]$ and $\mathrm{Zn}[\mathrm{e}]$ are the enrichment factors for $\mathrm{Cu}$ and $\mathrm{Zn}$, tie lines connect element enrichment factor ratios for first and second generation mineralization. Ag enrichment in the first generation event is 0 . Enrichments of $\mathrm{Pb}, \mathrm{Ag}, \mathrm{Au}$ and As all show a substantial increase relative to enrichment of $\mathrm{Cu}+\mathrm{Zn}$ from first to second generation events.

supported by the compositions of sphalerites associated with each event. To some extent, contrasts in compositions of the two generations of sphalerite parallel contrasts in whole rock enrichments. First generation sphalerites are relatively $\mathrm{Zn}$-rich, whereas the second generation sphalerites are relatively rich in $\mathrm{Fe}, \mathrm{Cd}$ and $\mathrm{Mn}$. The scatter exhibited by the second generation sphalerites may be in part due to changes in fluid composition during growth as indicated by growth zoning in individual crystals. 
Table 2. Microprobe analyses of sphalerite. All analyses in weight percent. First and second generation mineralization are indicated by $\mathrm{F}$ and $\mathrm{S}$ respectively. Sphalerites from samples 79A and 139 occur in second generation veins which cut mainly first generation and mineralization.

\begin{tabular}{|c|c|c|c|c|c|c|c|c|}
\hline Sample & $138 \mathrm{~A}-1$ & $138 \mathrm{~A}-2$ & $138 \mathrm{~A}-3$ & $79 \mathrm{~A}-1$ & $79 A-2$ & $79 A-3$ & $79 \mathrm{~A}-4$ & $79 A-5$ \\
\hline No. of Analyses & 1 & 2 & 1 & 3 & 3 & 3 & 3 & 1 \\
\hline Generation & $\mathrm{F}$ & $\mathrm{F}$ & $\mathrm{F}$ & S & $S$ & $S$ & $S$ & $S$ \\
\hline $\begin{array}{l}\mathrm{Fe} \\
\mathrm{Zn} \\
\mathrm{Cd} \\
\mathrm{Mn} \\
\mathrm{S}\end{array}$ & $\begin{array}{r}1.783 \\
64.690 \\
0.052 \\
0.018 \\
33.132\end{array}$ & $\begin{array}{r}2.016 \\
64.643 \\
0.093 \\
0.050 \\
33.107\end{array}$ & $\begin{array}{r}1.963 \\
64.987 \\
0.092 \\
0.048 \\
32.978\end{array}$ & $\begin{array}{r}4.680 \\
61.318 \\
0.173 \\
0.224 \\
33.372\end{array}$ & $\begin{array}{r}4.857 \\
61.164 \\
0.167 \\
0.250 \\
33.474\end{array}$ & $\begin{array}{r}4.573 \\
61.362 \\
0.187 \\
0.240 \\
33.256\end{array}$ & $\begin{array}{r}4.084 \\
61.769 \\
0.122 \\
0.185 \\
33.058\end{array}$ & $\begin{array}{r}5.687 \\
60.118 \\
0.156 \\
0.285 \\
33.481\end{array}$ \\
\hline Sample & $79 A-6$ & $139-1$ & $139-2$ & $139-3$ & $139-4$ & $139-5$ & $139-6$ & $139-7$ \\
\hline No. of Analyses & 1 & 1 & 1 & 1 & 4 & 4 & 5 & 5 \\
\hline Generation & $S$ & $S$ & $S$ & $S$ & $S$ & $S$ & $S$ & $S$ \\
\hline $\begin{array}{l}\mathrm{Fe} \\
\mathrm{Zn} \\
\mathrm{Cd} \\
\mathrm{Mn} \\
\mathrm{S}\end{array}$ & $\begin{array}{r}5.035 \\
60.837 \\
0.207 \\
0.196 \\
33.319\end{array}$ & $\begin{array}{r}5.117 \\
59.856 \\
0.241 \\
0.141 \\
32.958\end{array}$ & $\begin{array}{r}5.061 \\
60.144 \\
0.320 \\
0.111 \\
33.377\end{array}$ & $\begin{array}{r}5.024 \\
59.519 \\
0.232 \\
0.157 \\
33.298\end{array}$ & $\begin{array}{r}5.361 \\
60.414 \\
0.233 \\
0.146 \\
33.426\end{array}$ & $\begin{array}{r}5.384 \\
60.750 \\
0.246 \\
0.165 \\
33.354\end{array}$ & $\begin{array}{r}5.184 \\
60.910 \\
0.228 \\
0.176 \\
33.578\end{array}$ & $\begin{array}{r}4.889 \\
61.644 \\
0.257 \\
0.120 \\
33.225\end{array}$ \\
\hline
\end{tabular}

\section{Fluid inclusions}

\section{Analytical methods}

Three samples of second generation hydrothermal minerals, one containing sphalerite and two containing epidote, were studied for fluid inclusions. They were prepared at the Department of Earth Sciences, Memorial University of Newfoundland, as doubly-polished sections 0.5 to $2 \mathrm{~mm}$ thick, and were examined under a microscope in order to select suitable inclusions. Microthermometry was carried out using a Fluid Inc. adapted gas-flow U.S.G.S. heating/freezing system at the Department of Earth Sciences, Memorial University of Newfoundland, which had been standardized from -60 to $310^{\circ} \mathrm{C}$. Inclusion leakage was tested by repeating runs. All stage-obtained measurements have a precision of $2.5 \%$.

\section{Results}

The majority of fluid inclusions lie along growth zone planes in sphalerite, and along radial growth lines in epidote, and are thus considered to be primary (cf. Roedder, 1984). Most of the inclusions have diameters of less than 10 micrometers, and all except one are simple two-phase vapour-liquid inclusions. The relative paucity of reliable measurements reflects the small sizes of the inclusions, and the difficulty of viewing the sphaleritehosted inclusions because of the deep red colour of the host mineral.
Sphalcrite-hosted inclusions have homogenization temperatures ranging from 236 to $353^{\circ} \mathrm{C}$, and averaging $306^{\circ} \mathrm{C}$ (Fig. 7). Epidote-hosted inclusions (not shown on Fig. 7) show a wide scatter and non-normal distribution of homogenization temperatures. Salinities calculated from final ice melting temperatures for epidote $(0,1.6,1.7,3.3,5.2,10.7$ eq. wt. $\% \mathrm{NaCl})$ and sphalerite $(0.1,4.1,4.3,5.3,5.7,7.3,12.1,12.8$ eq. wt. \% $\mathrm{NaCl})$ are widely variable. Estimates of initial ice melting temperatures ranged from -63.9 to $-18.4^{\circ} \mathrm{C}$, indicating that at least some of the inclusions contain $\mathrm{NaCl}, \mathrm{KCl}$, and possibly $\mathrm{CaCl}_{2}$, as the systems $\mathrm{NaCl}-\mathrm{H}_{2} \mathrm{O}, \mathrm{NaCl}-\mathrm{KCl}-\mathrm{H}_{2} \mathrm{O}$ and $\mathrm{CaCl}_{2}-\mathrm{H}_{2} \mathrm{O}$ have eutectic temperatures of $-20.8,-23.2$, and $-52^{\circ} \mathrm{C}$ respectively (Crawford, 1981). One inclusion developed a clathrate which melted at $+12.5^{\circ} \mathrm{C}$.

Spooner (1981) has summarized fluid inclusion data from various types of mineral deposits. Fluid inclusions from epithermal $\mathrm{Au}-\mathrm{Ag}-\mathrm{Cu}-\mathrm{Pb}-\mathrm{Zn}$ veins or replacement deposits, deposits associated with igneous intrusions, and Archean lode gold deposits have homogenization temperature ranges of $200-330^{\circ} \mathrm{C}, 200$ $400^{\circ} \mathrm{C}$ and $200-490^{\circ} \mathrm{C}$ respectively, and salinity ranges of $0.5-$ $12 \%, 5.0-10.0 \%$ and $2.0-4.0$ eq. wt. \% NaCl, respectively. Our fluid inclusion data do not constrain the Lake Bond second generation mineralization to any of these types. The observed clathrate had a melting temperature of $+12.5^{\circ} \mathrm{C}$, and, therefore, may have been the $\mathrm{CO}_{2}$ clathrate phase, $\mathrm{CO}_{25} 3 / 4 \mathrm{H}_{2} \mathrm{O}$. If this is the case, it supports interpretations from petrography and geochemistry that $\mathrm{CO}_{2}$ was a constituent of the second generation fluids. 


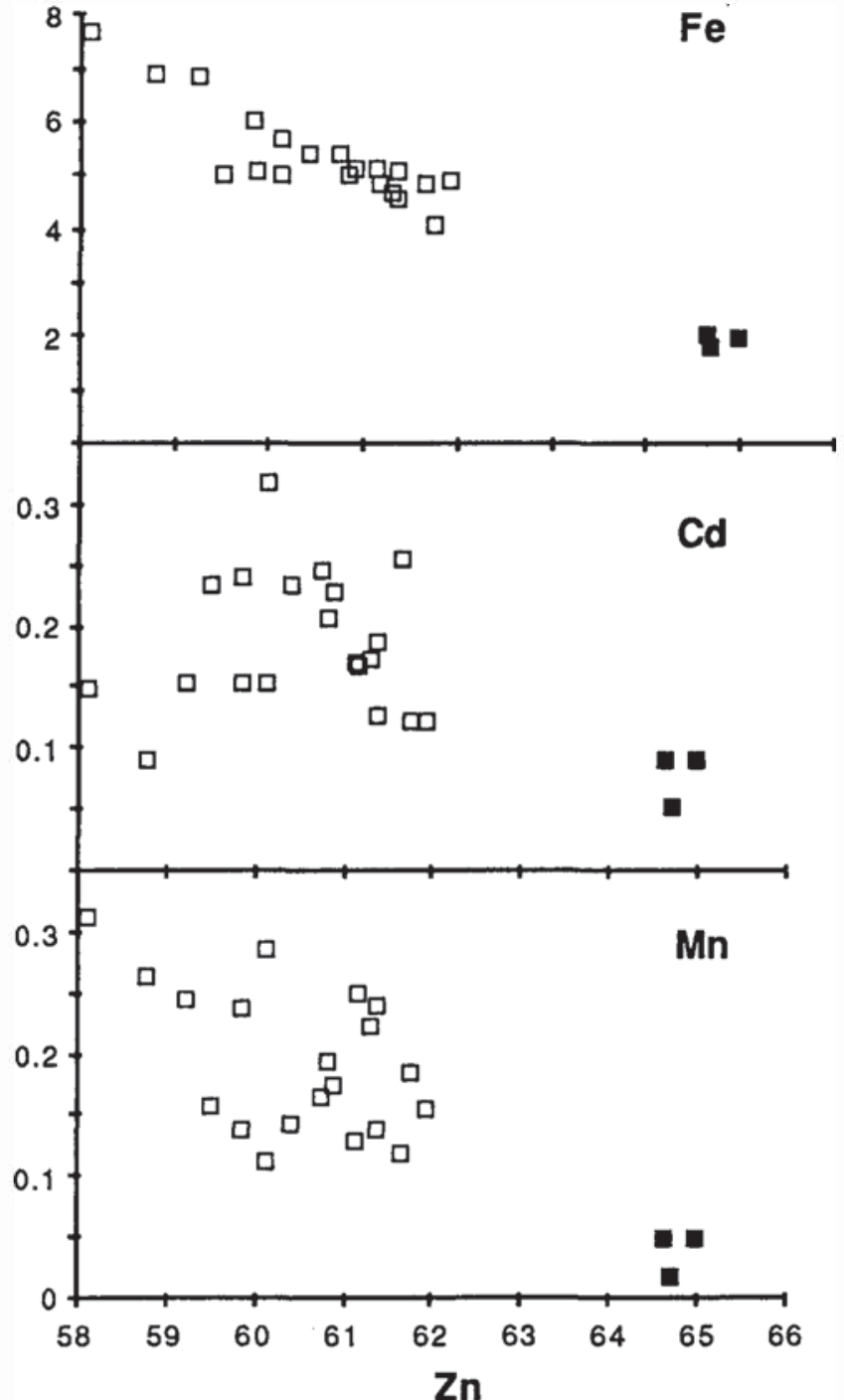

Fig. 6. Comparison of the composition of first and second generation sphalerite from the Lake Bond deposit. Closed symbols = first generation mineralization; open symbols = second generation mineralization. Values in weight percent.

\section{DISCUSSION}

\section{Base and precious metal metallogeny of central Newfoundland}

Cambrian and Early Ordovician volcanogenic massive sulphide (VMS) mineralization is widespread in oceanic volcanic sequences of central Newfoundland (e.g., Dean, 1978; Swinden and Kean, 1984; Swinden et al., 1988). There are more than 30 deposits with quoted production and/or reserves of more than 200,000 tonnes and scores of minor deposits and occurrences. Base and precious metal contents and ratios vary widely among the deposits, and the relative contents of the various metals is closely related to the composition of volcanic rocks in the underlying volcanic sequences. Copper, zinc and gold are most abundant in deposits with dominantly mafic and ultramafic substrates whereas increasing abundances of felsic volcanic rocks in the substrate are correlated with relative enrichments in

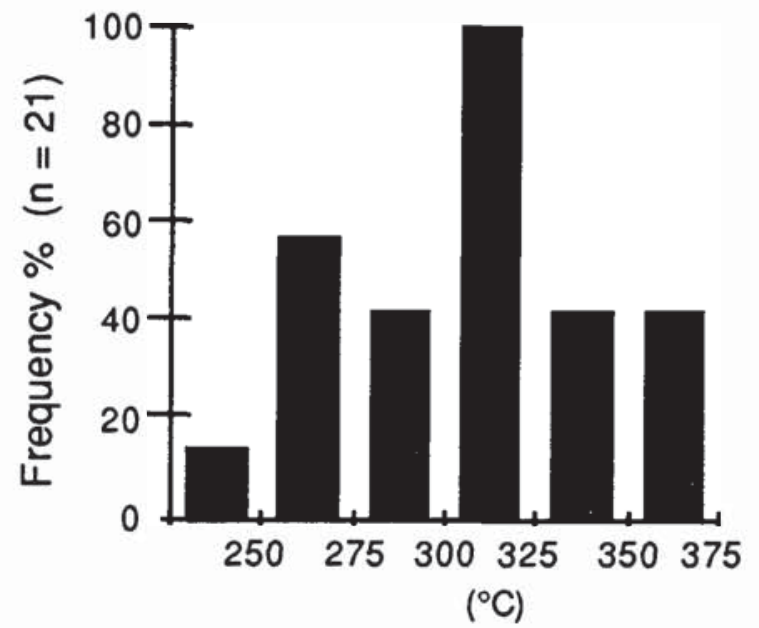

Fig. 7. Histogram of homogenization temperatures of fluid inclusions in second generation sphalerite.

$\mathrm{Pb}$ and $\mathrm{Ag}$ (Swinden and Kean, 1984; Swinden and Thorpe, 1984; Swinden et al., 1988).

However, it has been recognized in recent years that there is a second regional metallogenic event in Central Newfoundland, in which auriferous mineralization is associated with linear structural features of regional extent. This mineralizing event, probably Silurian to Early Devonian (Tuach et al., 1988), is responsible for recently-discovered gold deposits on the Baie Verte Peninsula (Gower et al., 1988; Tuach et al., 1988), western White Bay (Tuach, 1986, 1987; Tuach and French, 1986; Saunders and Tuach, 1988), the eastem boundary of the Dunnage Zone (e.g., Little River, Meikle, 1955; Dickson, 1988) and perhaps the Hope Brook and Cape Ray deposits in southern Newfoundland (Wilton and Strong, 1986; O'Brien, 1989). The event produced structurally-controlled, lode and disseminated type deposits which commonly contain minor enrichments in $\mathrm{Cu}$ or $\mathrm{Zn}$, but substantial enrichments in $\mathrm{Au}, \mathrm{As}$ and $\mathrm{Sb}$. This metal association also is reflected in regional patterns of lake sediment geochemistry (Davenport, 1988; Davenport and McConnell, 1988; Davenport and Nolan, 1989); extensive Au, Sb and locally As and $\mathrm{W}$ anomalies form geochemical haloes along the traces of major auriferous structures throughout central Newfoundland. These patterns, well documented in the Baie Verte Peninsula, White Bay, and eastern Dunnage Zone areas, have been tentatively related to the existence of large hydrothermal systems operating along these major structures (Davenport and Nolan, 1989).

Deposits of the two types occur in proximity to each other in at least two areas. On the Baie Verte Peninsula, well known VMS deposits in mafic-dominated volcanic sequences such as the Rambler deposits (Tuach and Kennedy, 1978; Tuach, 1988b), Tilt Cove (Hurley and Crocket, 1985; Saunders and Strong, 1988 ) and others are closely associated spatially with younger lode gold mineralization such as the Deer Cove deposit (Gower et al., 1988). The Victoria Lake Group in south-central Newfoundland hosts the well known VMS deposits of the Tulks Valley (Barbour and Thurlow, 1982; Kean and Evans, 1986) as well as younger auriferous deposits in shear zones characterized 
by aluminous and potassic alteration (e.g., Midas Pond, Evans and Kean, 1987). In both areas, the later, epigenetic auriferous mineralizing event is distinguished from the VMS deposits by distinctive alteration patterns, relative enrichments in $\mathrm{Au}, \mathrm{As}$ and/or Sb and structural style.

Kerrich and Hodder (1982) showed that the two principal types of Archean Au deposits, lode gold and volcanogenic massive sulphides, show somewhat similar contrasts in metal enrichment patterns. Massive sulphides tend to show considerably greater enrichments of $\mathrm{Cu}$ and $\mathrm{Zn}$ relative to gold than the lode deposits, which are commonly gold-rich with minor base metals. Lode deposits also are locally enriched in As, Sb and/or granophile elements such as $W$ relative to the host volcanic rocks. Kerrich and Fryer (1981) and Kerrich and Hodder (1982) attributed these contrasting enrichment patterns to contrasts in both source areas and fluid histories of the two types of mineralization.

Kerrich and Hodder (1982) presented a diagram to distinguish Archean lode gold from massive sulphide deposits based on relative enrichments of $\mathrm{Au}, \mathrm{Cu}$ and $\mathrm{Zn}$. When plotted on this diagram (not shown), most second generation samples from Lake Bond plot close to the massive sulphide rather than the lode gold field, reflecting the fact that, unlike typical Archean lode deposits, they are substantially enriched in $\mathrm{Cu}+\mathrm{Zn}$ as well as $\mathrm{Au}$. Because epigenetic mineralization at Lake Bond is superimposed on an earlier $\mathrm{Cu}-\mathrm{Zn}$ deposit, this may reflect remobilization and reconcentration of $\mathrm{Cu}$ and $\mathrm{Zn}$ during the later event. This being the case, some of the distinction between lode Au and base metal processes in the Lake Bond deposit that would have resulted from contrasting source rocks and fluid histories may have been severely modified (and the distinctions blurred) by processes at the depositional site.

\section{Origin of two-stage mineralization at Lake Bond}

The characteristics of the two mineralizing events recognized at Lake Bond are summarized in Table 3. Comparisons with analogous deposits elsewhere in central Newfoundland and with possible Archean analogues where volcanogenic and later lode gold deposits coexist (e.g., Kerrich and Fryer, 1981; Kerrich and Hodder, 1982) suggest that this deposit comprises an early volcanogenic stockwork style of mineralization which has been overprinted by a later hydrothermal event related to folding and shearing. This model for two-stage mineralization is illustrated in Figure 8.

During the first stage of mineralization, circulation of sea water in a sub-seafloor hydrothermal cell leached metals from the volcanic substrate in approximately the proportions in which they were present in the source rocks (cf. Kerrich and Hodder, 1982). Ascent of the heated water to near the sea floor resulted in pervasive chloritization and pyritization of the basalts and a locally more intense quartz-sericite alteration. Pyrite, $\mathrm{Fe}-\mathrm{Cd}$ Mn-poor sphalerite and chalcopyrite were deposited. This mineralizing event, if it is indeed volcanogenic, must be about the same age as the host rocks, approximately $473 \mathrm{Ma}$ (Dunning $e t$ al., 1987).

At some later time, the Robert's Arm Group was penetratively deformed, sheared and dismembered. The main stage of deformation involved shearing of the volcanic rocks and the pre-

Table 3. Summary of geological and geochemical contrasts between first and second generation mineralization at the Lake Bond deposit. Mineral abbreviations as in Figure 3.

\begin{tabular}{|c|c|c|}
\hline & First Generation & Second Generation \\
\hline Form of Mineralization & $\begin{array}{l}\text { Whole-rock replacement, } \\
\text { disseminations and veins }\end{array}$ & Veins \\
\hline Ore Mineralogy & Py, Sp, Cp & $\mathrm{Sp}, \mathrm{Cp}, \mathrm{Gn} \pm \mathrm{Py} \pm \mathrm{Au}$ \\
\hline Gangue Mineralogy & $\mathrm{Ch}, \mathrm{Qz}, \pm \mathrm{Se}$ & $\mathrm{Ep}, \mathrm{Ca}, \mathrm{Qz}, \mathrm{Cz}, \mathrm{Ga}$ \\
\hline Sphalerite Chemistry & Relatively Zn-rich & Relatively $\mathrm{Fe}, \mathrm{Cd}, \mathrm{Mn}$ rich \\
\hline $\begin{array}{l}\text { Chemical changes } \\
\text { (Enrichments or Depletions) }\end{array}$ & $\begin{array}{l}+\mathrm{FeOt}, \mathrm{MnO} ;-\mathrm{CaO} \\
+\mathrm{Cu}, \mathrm{Zn} \pm \mathrm{Cd}\end{array}$ & $\begin{array}{l}+\mathrm{FeO}, \mathrm{MnO}, \mathrm{K}_{2} \mathrm{O} \\
+\mathrm{Cu}, \mathrm{Zn}, \mathrm{Pb}, \mathrm{Ag}, \mathrm{Au}, \mathrm{As}, \mathrm{Cd}, \\
\pm \mathrm{Mo}\end{array}$ \\
\hline Fluid Inclusions & N. A. & $\begin{array}{l}\mathrm{T}_{\mathrm{H}}=\sim 306^{\circ} \mathrm{C}, \\
\text { Salinity-variable, } \\
<13 \text { eq. wt. } \% \mathrm{NaCl}\end{array}$ \\
\hline Style of Deformation & $\begin{array}{l}\text { Pre-Kinematic } \\
\text { Sheared and Foliated }\end{array}$ & $\begin{array}{l}\text { Syn- to Post-Kinematic } \\
\text { Some veins sheared and } \\
\text { banded }\end{array}$ \\
\hline Timing of Mineralization & Early Ordovician & Probably Early Silurian \\
\hline
\end{tabular}



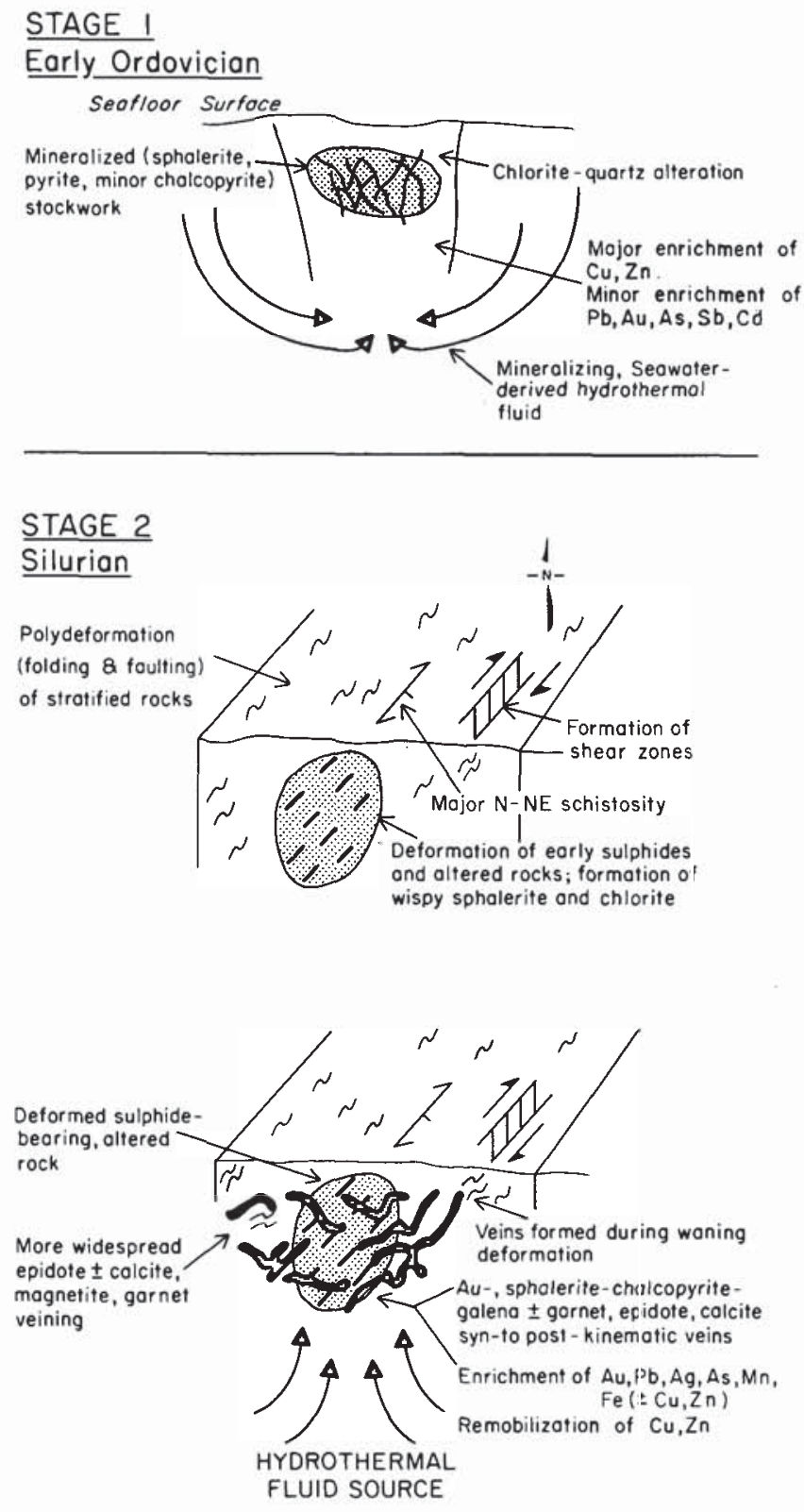

Fig. 8. Schematic model for two-stage mineralization history of the Lake Bond deposit. See text for discussion.

existing volcanogenic sulphide deposits, and, at least in its latter stages, was accompanied by renewed hydrothermal activity. The second generation hydrothermal fluids deposited epidote-chlorite-garnet, pyrite, $\mathrm{Fe}-\mathrm{Cd}-\mathrm{Mn}$-rich sphalerite, chalcopyrite and minor galena in syn- and post-tectonic vein systems and stockworks, overprinting the pre-existing sulphide stockwork and extending beyond it for some distance. Although the $\mathrm{Ca}-\mathrm{Fe}-\mathrm{Mg}$ silicate veins were deposited over a wider area than the earlier alteration, most of the base and precious metal-bearing second generation veins were confined within the pre-existing sulphide deposit. This may be due either to the reducing nature of the rocks in the sulphide-rich zone or to the local availability of sulphur. Some first generation $\mathrm{Zn}$ and $\mathrm{Cu}$ (and perhaps other metals as well, e.g., $\mathrm{Cd}, \mathrm{Sb}$ ) were probably remobilized from the preexisting deposit to form second generation sphalerite and chal- copyrite, possibly explaining the anomalous enrichment of $\mathrm{Cu}$ and $\mathrm{Zn}$ in these deposits relative to Archean lode gold deposits.

Fluid inclusion data suggest that the second stage hydrothermal fluids were approximately $300^{\circ} \mathrm{C}$, contained less than about 13 eq. wt. \% $\mathrm{NaCl}$ (although this is not well constrained by our data), and were probably $\mathrm{CO}_{2}$-bearing. The $\mathrm{Ca}-\mathrm{Fe}-\mathrm{Mg}$ vein silicates place further constraints on the fluid temperatures and source(s). Calc-silicates are an important group of rock- and vein-forming minerals throughout geothermal areas with widely differing protoliths (i.e., volcanic, sedimentary, metamorphic rocks) and brine compositions (Bird et al., 1984). In these settings, epidote, clinozoisite and tremolite-actinolite usually occur within the range of temperatures from $200^{\circ} \mathrm{C}$ to greater than $300^{\circ} \mathrm{C}$, whereas garnet typically is found at temperatures greater than $300^{\circ} \mathrm{C}$.

The timing of the second generation mineralizing event can be relatively well constrained by geological data. The main schistosity in the SRAG also affected fossiliferous Lower Silurian flysch (the Sansom Greywacke and equivalents) and the mineralization must be younger than this. First deformation fabrics in the Robert's Arm Group near Great Gull Pond are overprinted by a syn- to post-tectonic metamorphic overprint related to intrusion of the Twin Lakes granodiorite (Upadhyay and Smitheringale, 1972), on which there is a preliminary U/Pb (zircon) age of approximately $435 \mathrm{Ma}$ (G.R. Dunning, B.J. Fryer, personal communication, 1989), early Silurian according to most Paleozoic time scales. The second generation mineralization is, therefore, probably early Silurian in age. This is consistent with evidence for timing of gold mineralization in western White Bay (Tuach, 1987; Saunders and Tuach, 1988) and in the Victoria Lake Group (Kean and Evans, 1988) suggesting that mineralization in these three areas was probably related to the same, regionally extensive, metallogenic event.

The anomalous enrichments in $\mathrm{Pb}$ and $\mathrm{Ag}$ with respect to $\mathrm{Cu}$ and $\mathrm{Zn}$ in the second generation mineralization may indicate that some of the second generation metal sources were sialic rather than oceanic volcanic. This is consistent with the interpretation of this mineralizing event as a regional hydrothermal event, rclated to post-accretion (i.e., post-cratonization) shearing and strike-slip reactivation of major faults. Deep metal sources at this time would have included continental crust, probably Grenvillian, upon which the volcanic sequences were emplaced during the Taconian orogeny (Marillier et al., 1989). However, the contrasts in metal enrichments and alteration patterns between the two types of mineralization may also require substantial contrasts in fluid histories and depositional processes.

\section{COMPARISON WITH OTHER PROSPECTS IN THE SOUTHERN ROBERT'S ARM GROUP}

The recognition of a two-stage mineralization history in the Lake Bond deposit has significant consequences for exploration in the SRAG and, indeed, for the whole Buchans-Robert's Arm belt. Previously considered as prospective for volcanogenic base metal deposits only, this belt would appear to be also prospective for epigenetic gold mineralization. The fact that, at least in the Lake Bond area, the second generation auriferous mineralization 
has locally overprinted the earlier volcanogenic event, suggests that all alteration zones in the area (Fig. 2, see Swinden, 1988 for detailed descriptions) should be re-evaluated as possible gold targets. Although data are not complete, indications are that at least some of these deposits deserve particular attention.

\section{The Handcamp Prospect}

The Handcamp Prospect, approximately $10.5 \mathrm{~km}$ north of Gullbridge, comprises a roughly $50 \mathrm{~m}$ wide alteration zone containing chalcopyrite, sphalerite, galena, and sporadic concentrations of gold and silver. It has been traced for about $1200 \mathrm{~m}$ along strike. Hudson and Swinden (1989) recently have described detailed mapping and geochemical studies in the vicinity of this occurrence.

Although there may be pre-tectonic alteration and mineralization at Handcamp, the evidence is not as clear as at Lake Bond. Petrographic observations indicate that pre- or syn-kinematic disseminated pyrite, magnetite, and minor sphalerite and chalcopyrite are associated with quartz-sericite-pyrite alteration assemblages. Syn- to post-kinematic veins contain pyrite, magnetite, zoned sphalerite, barite, with minor galena and chalcopyrite in a gangue rich in $\mathrm{Ca}-\mathrm{Mg}-\mathrm{Fe}$ silicates and carbonates, including epidote, garnet, tremolite, quartz, wollastonite, calcite, clinozoisite and magnetite. Epidote alteration is common to all lithologies, and extends beyond the limits of sulphide mineralization.

The patterns of metal enrichment at Handcamp are similar to the second generation mineralization at Lake Bond (Fig. 9). Substantial enrichments of $\mathrm{C}$ and $\mathrm{Zn}$ are parallelled by $\mathrm{Pb}, \mathrm{Ag}$ and $\mathrm{Au}$, and the "gold tracers", As and Sb. Cd was only enriched in a couple of samples and could not be used in the metasomatic calculations. As the evidence for a pre-tectonic mineralizing event was not clear, it was impossible to separate 'pre-tectonic' ('primary') samples for metasomatic calculations.

Syn- and post-kinematic mineralization at Handcamp apparently is related to intense shearing which is parallel to, and probably the same generation as, the deformation related to second generation mineralization at Lake Bond.

Hudson and Swinden (1989) interpreted the Handcamp Prospect to be a structurally controlled, probably Silurian, shearhosted deposit. They noted that this was the first documentation of this deposit type in the Buchans-Robert's Arm belt, although there are examples in adjacent sequences to the east and west which currently are being intensively explored. In view of the close geological, petrological and geochemical similarity between the auriferous mineralization at Handcamp and the second generation mineralization at Lake Bond, it seems reasonable to correlate them. The Silurian auriferous mineralizing event that is receiving extensive exploration elsewhere in Newfoundland, would seem to be more widespread in the Buchans-Robert's Arm Belt than has been recognized previously.

\section{Mineral Point Alteration Zone}

The Gullbridge and Southwest Shaft deposits are the principal deposits in a sheared alteration zone that can be traced for

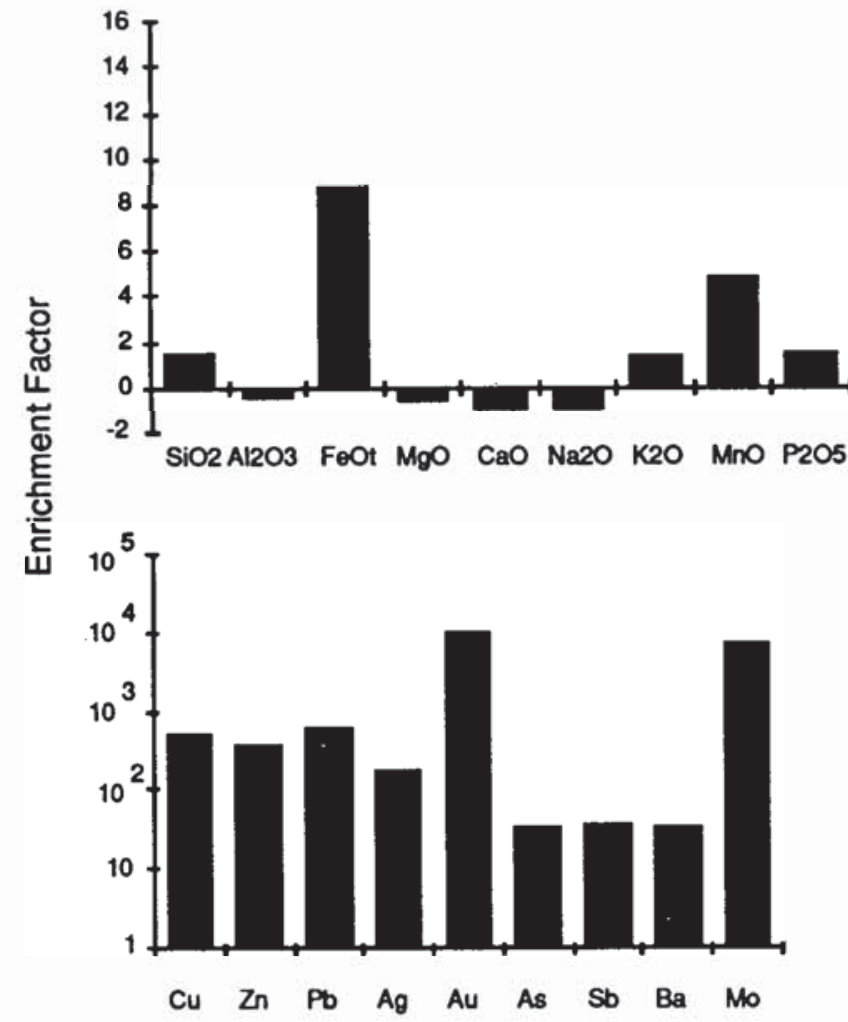

Fig. 9. Metasomatic enrichment/depletion diagrams for the Handcamp prospect with respect to the reference Bumt Island basalt sample (Table 1).

more than $4 \mathrm{~km}$ along strike (Swinden and Sacks, 1986; Swinden, 1988, fig. 2). Both deposits are dominantly cupriferous, with lesser pyrite, pyrrhotite and minor sphalerite, hosted by mafic volcanics with a cordierite-anthophyllite-chlorite alteration assemblage that apparently reflects thermal metamorphism of a volcanogenic stockwork zone (Upadhyay and Smitheringale, 1972; Bachinski, 1973, 1976).

There are no reported examples of anomalous Au contents in samples from the Gullbridge Mine. However, anomalous gold contents (up to $590 \mathrm{ppb}$ ) have been detected in samples collected from the dump at the Southwest Shaft deposit (Swinden, 1988). These auriferous samples are all cut by post-kinematic veins containing chalcopyrite, pyrite and randomly oriented biotite. Similar veins were documented in the Gullbridge deposit by Upadhyay (1970) who also reported local occurrences of garnet, diopside, vesuvianite, and late sphalerite and galena. No gold data are available for these samples.

Deformed samples without post-kinematic veins in the Southwest Shaft area, as well as samples of this nature collected from the mine dumps at Gullbridge, always contain $<100 \mathrm{ppb} A u$ (sce also Swinden, 1988). Elevated Au contents at Southwest Shaft are accompanied by elevated Mo (up to $26 \mathrm{ppm}$ ), and to a lesser extent, Co (up to $960 \mathrm{ppm}$ ); the samples show variable enrichments of $\mathrm{Cu}$ (up to $>4000 \mathrm{ppm}$ ), $\mathrm{Ba}$ (up to $18800 \mathrm{ppm}$ ) and As (up to $280 \mathrm{ppm}$ ) with generally low $\mathrm{Pb}, \mathrm{Ag}$ and $\mathrm{Sb}$.

Considering the preference that the auriferous mineralization seems to show for pre-existing sulphide zones in the Lake Bond area, a re-evaluation of these deposits may be appropriate, 
looking for evidence of Au-bearing zones within the earlier volcanogenic sulphide occurrences. A detailed study for evidence of post-kinematic mineralization and possible gold enrichments would appear to be warranted.

\section{West Zone}

The West Zone consists of sulphide-rich zones, up to $40 \mathrm{~cm}$ wide, in highly silicified and sheared felsic volcanic rocks. A massive pod of pyrite, $50 \mathrm{~cm}$ by $10 \mathrm{~cm}$, is wedged into the altered rocks. Minor, post-kinematic, sphalerite-bearing veinlets are present locally.

The occurrence contains elevated gold values $(230 \mathrm{ppb}$, Swinden, 1988) in a single sample, accompanied by anomalous $\mathrm{Pb}(52 \mathrm{ppm}), \mathrm{Ag}$ (43 ppm), As (100 ppm) and Mo (60 ppm). By analogy with the Lake Bond and Handcamp areas, these minor gold enrichments may be related to the same syn-to post-kinematic Au-mineralizing event. Further evaluation of this and other similar alteration zones with related shearing throughout the SRAG is clearly warranted.

\section{CONCLUSIONS}

Detailed geological, petrological and geochemical studies of the Lake Bond deposit reveal a two-stage sulphide mineralization history. Pre-kinematic pyrite and base metal sulphide mineralization associated with pervasive chloritization is interpreted to represent a Early Ordovician volcanogenic mineralizing event. Syn-and post-kinematic mineralization is characterized by anomalous enrichments in $\mathrm{Au}, \mathrm{Pb}$ and $\mathrm{Ag}$ and is associated with $\mathrm{Ca}-\mathrm{Mg}-\mathrm{Fe}$ carbonates and silicates in the gangue. Mineral assemblages in the gangue and sphalerite fluid inclusion data suggest that this was a relatively high temperature event and it is interpreted to record an early Silurian epigenetic event, related to hydrothermal activity accompanying movement on major faults and shear zones.

The two generations of mineralization are distinguished geochemically by element enrichments in the gangue and by metal enrichment patterns in the sulphides. Sphalerites from the two major mineralization stages at Lake Bond have distinct compositions that parallel compositional differences in the whole rocks. These distinct geochemical associations probably reflect differences in both fluid genesis and source areas. Earlier deformed rocks contain $\mathrm{Cu}-\mathrm{Zn}$ mineralization, more indicative of a volcanogenic origin and derivation of the metals from the oceanic, dominantly mafic, volcanic pile. The fact that $\mathrm{Cu}, \mathrm{Zn}$ and $\mathrm{Au}$ are enriched to a similar degree over the source basalts in the first generation event may reflect the action of halogen-rich sea water and relatively high water-rock ratios (e.g., Kerrich and Hodder, 1982) in which the solubility of the base metals is not limited by the availability of chloride for complexing. The enrichment in $\mathrm{Pb}, \mathrm{Au}, \mathrm{As}$, and $\mathrm{Ag}$ relative to $\mathrm{Cu}$ and $\mathrm{Zn}$ in the second generation is similar to that in the probably epigenetic Handcamp deposit to the north and is reminiscent of mesothermal lode gold deposits (Kerrich and Hodder, 1982; Kerrich, 1989). Substantial absolute enrichments of $\mathrm{Cu}$ and $\mathrm{Zn}$ in the second generation event may partly reflect reconcentration of earlier $\mathrm{Cu}$ and $\mathrm{Zn}$. The enrichment of $\mathrm{Pb}$ and $\mathrm{Ag}$ may suggest a sialic crustal source for the metals, consistent with their deposition following accretion of the host oceanic volcanic rocks to the North American continental margin. Alternatively, these enrichments may reflect different hydrothermal fluid histories. The association of $\mathrm{Ca}-\mathrm{Mg}$ - $\mathrm{Fe}$ silicates with the second generation gold-sulphide veins and fluid inclusion data suggest fluid temperatures of $>200^{\circ} \mathrm{C}$, and possibly as high as $>300^{\circ} \mathrm{C}$. The ubiquitous presence of carbonate suggests that $\mathrm{CO}_{2}$-rich fluids may have been prevalent in the mineralizing process. Further fluid inclusion work may substantiate this, as only one $\mathrm{CO}_{2}$ bearing clathrate has been detected to date.

The spatial association of Au-bearing veins with earlier, deformed sulphide zones suggests that the latter may have supplied metals and sulphur to the Au-bearing fluids. This may explain the anomalous enrichment of $\mathrm{Cu}$ and $\mathrm{Zn}$ in second generation mineralization at Lake Bond relative to most lode gold deposits (Kerrich and Hodder, 1982). Au precipitation may have been favoured by the presence of sulphides. Exploration efforts directed at identifying second generation mineralization overprinting older volcanogenic sulphide zones may meet with success.

The identification of the syn- to post-kinematic mineralization in the SRAG suggests that current models of metallogenesis in central Newfoundland as a whole (Tuach et al., 1988), involving Cambrian to mid-Ordovician base metal-rich volcanogenic mineralization, succeeded by Silurian or later auriferous mineralization associated with shearing and movement on major faults, can be applied to the Buchans-Roberts Arm belt. The metallogenic association in the Lake Bond deposit, in the broadest sense, can be viewed as reflecting processes typical of the pre-accretion and post-accretion orogen, respectively, as represented in the Central Newfoundland Appalachians.

\section{ACKNOWLEDGEMENTS}

This research was funded by the Geological Survey of Canada under the Canada-Newfoundland Mineral Development Agreement, 1984-1989. Paul Sacks, Paul Deering, and Lorne Garnier provided able field assistance during 1985 and 1986. Tyson Birkett and Dan Richardson of the GSC provided greatly appreciated logistical support.

The chemical analyses were carried out under contract to the GSC. $\mathrm{Cu}$ and $\mathrm{Zn}$ were analysed at the laboratories of the Newfoundland Department of Mines. G.M. LeCheminant of the GSC carried out the sphalerite microprobe analyses. Fluid inclusion work was carried out at the Department of Earth Sciences, Memorial University of Newfoundland. Drafting and photomechanical support from the cartography section of the Newfoundland Department of Mines and Energy is acknowledged.

Baxter Kean and Mark Wilson critically read an early version of the manuscript and made many useful comments. We thank Derek Wilton and one anonymous journal reviewer for critical comments that substantially improved the final manuscript . 
BACHINSKI, D.J. 1973. Metamorphism of cupriferous iron-sulphiderich rocks in ophiolitic terranes. Ph.D. thesis, Yale University, 212 p.

- 1976. Alteration associated with metamorphosed ophiolitic cupriferous iron sulphide deposits: Whalesback Mine, Notre Dame Bay, Newfoundland. Mineralium Deposita, 12, pp. 48-63.

BARBOUR, D.M. and THURLOW, J.G. 1982. Case histories of two massive sulphide discoveries in central Newfoundland. In Prospecting in areas of glaciated terrain. Edited by P.H. Davenport. Canadian Insititute of Mining and Metallurgy, Geological Division, Montreal, pp. 300-320.

BIRD, D.K., SCHIFFMAN, P., ELDERS, W.A., WILLIAMS, A.F., and MCDOWELL, S.D. 1984. Calc-silicate mineralization in active geothermal systems. Economic Geology, 79, pp. 671-695.

CONSOLIDATED MORRISON EXPLORATION LIMITED. 1977. Diamond drill records for the Lake Bond Property with accompanying report. Unpublished report, 2 p.

CRAWFORD, M.L. 1981. Phase equilibria in aqueous inclusions. Mineralogical Association of Canada, Short Course in Fluid Inclusions: Applications to Petrology. Edited by L.S. Hollister and M.L. Crawford, pp. 75-100.

DAVENPORT,P.H. 1988. The use of multi-element neutron activation analysis of organic lake sediment in geochemical exploration for gold. In Current Research, Newfoundland Department of Mines, Mineral Development Division, Report 88-1, pp. 403-414.

DAVENPORT, P.H. and MCCONNELL, J.W. 1988. Lake sediment geochemistry in regional exploration for gold. In Prospecting in Areas of Glaciated Terrain - 1988. Edited by D.R. MacDonald and K.A. Mills. Canadian Institute of Mining, Geology Division Publication, pp. 333-356.

DAVENPORT, P.H. and NOLAN, L.W. 1989. Mapping regional distribution of gold in Newfoundland using lake sediment geochemistry. In Current Research, Newfoundland Department of Mines, Geological Survey of Newfoundland, Report 89-1, pp. 259 266.

DEAN, P.L. 1978. The volcanic stratigraphy and metallogeny of Notre Dame Bay. Memorial University of Newfoundland, St. John's, Newfoundland, Geological Report 7, 204 p.

DEAN, P.L. and STRONG, D.F. 1976. Geological compilation maps for Notre Dame Bay. Newfoundland Department of Mines and Energy, Mineral Development Division, Open File 947.

DICKSON, W.L. 1988. Geology and mineralization in the Hungry Grove Pond (1M/14) map area, southeastem Newfoundland. In Current Research, Newfoundland Department of Mines, Mineral Development Division, Report 88-1, pp. 145-164.

DUNNING, G.R., KEAN, B.F., THURLOW, J.G., and SWINDEN, H.S. 1987. Geochronology of the Buchans, Robert's Arm, and Victoria Lake Groups and Mansfield Cove Complex, Newfoundland. Canadian Joumal of Earth Sciences, 24, pp. 1175-1184.

EVANS, D.T.W. and KEAN, B.F. 1987. Gold and massive sulfide mineralization in the Tulks Hill volcanics, Victoria Lake Group, Central Newfoundland. In Current Research, Newfoundland Department of Mines and Energy, Mineral Development Division, Report 87-1, pp. 103-111.

GOWER, D., GRAVES, G., WALKER, S., and MACINNIS, D. 1988. Lode gold mineralization at Deer Cove, Point Rousse Complex, Baie Verte Peninsula. In The Volcanogenic Sulphide Districts of Central Newfoundland. Edited by H.S. Swinden and B.F. Kean. Geological Association of Canada, Mineral Deposits Division, pp. 43-48.

GRANT, J.A. 1986. The isocon diagram - a simple solution to Gresen's equation for metasomatic alteration. Economic Geology, 81, pp.
1976-1982.

GRESENS, R.L. 1967. Composition-volume relationships of metasomatism. Chemical Geology, 2, pp. 47-55.

HUDSON, K.A. and SWINDEN, H.S. 1989. Geology and petrology of the Handcamp gold prospect, Robert's Arm Group, Newfoundland. In Current Research, Part B, Geological Survey of Canada, Paper 89-1B, pp. 93-105.

HURLEY,T.D. and CROCKET, J.H. 1985. A gold-sphalerite association in a volcanogenic base-metal-sulphide deposit near Tilt Cove, Newfoundland. Canadian Mineralogist, 23, pp. 423-430.

KEAN, B.F. and EVANS, D.T.W. 1986. Metallogeny of the Tulks Hill volcanics, Victoria Lake Group, central Newfoundland. In Current Research, Newfoundland Department of Mines and Energy, Mineral Development Division, Report 86-1, pp. 51-57.

. 1988. Regional metallogeny of the Victoria Lake Group. In Current Research, Newfoundland Department of Mines, Mineral Development Division, Report 88-1, pp. 319-330.

KERRICH, R. 1989. Geochemical evidence on the sources of fluids and solutes for shear-hosted mesothermal Au deposits. In Mineralization and Shear Zones. Edited by J.T. Bursnall. Geological Association of Canada, Short Course Notes Volume 6, pp. 129. 197.

KERRICH, R. and FRYER, B.J. 1981. The separation of rare elements from abundant base metals in Archean lode gold deposits: Implications of low water/rock source regions. Economic Geology, 77, pp. 160-166.

KERRICH, R. and HODDER, R.W. 1982. Archean lode gold and base metal deposits: chemical evidence for fractionation into independant hydrothermal reservoirs. In Canadian Institute of Mining and Metallurgy, Special Volume 24. Edited by R.W. Hodder and W. Petruk, pp. 144-160.

KIRKHAM, R.V., editor. 1987. Buchans Geology, Newfoundland. Geological Survey of Canada, Paper 86-24, 288 p.

MARILLIER, F., KEEN, C.E., STOCKMAL, G.S., QUINLAN, G., WILLIAMS, H., COLMAN-SADD, S.P., and O'BRIEN, S.J. 1989. Crustal structure and surface zonation of the Canadian Appalachians. Canadian Journal of Earth Sciences, 26, pp. 305 321.

MEIKLE, B.K. 1955. The geology of the Little River area, Bay d'Espoir. Unpublished M.Sc. thesis, McGill University, Montreal, $43 \mathrm{p}$.

O'BRIEN, B.H. 1989. Summary of the geology between La Poile Bay and Couteau Bay (110/9 and 110/16), Southwestern Newfoundland. In Current Research, Newfoundland Department of Mines, Geological Survey Branch, Report 89-1, pp. 105-119.

ROEDDER, E. 1984. Fluid inclusions. Mineralogical Society of America Review of Earth and Planetary Sciences, 8, pp. 263-301.

SAUNDERS, C.M. and STRONG, D.F. 1988. Ophiolitic sulfide mineralization at Tilt Cove, Newfoundland: controls by upper mantle and crustal processes. Economic Geology, 83, pp. 239-255.

SAUNDERS, C.M. and TUACH, J. 1988. K-feldspathization, albitization and gold mineralization in granitoid rocks: the Rattling Brook alteration system, Western White Bay, Newfoundland. In Current Research, Newfoundland Department of Mines, Mineral Development Division, Report 88-1, pp. 307-317.

SPOONER, E.T.C. 1981. Fluid inclusion studies in hydrothermal ore deposits. In Fluid Inclusions: Applications to Petrology. Edited by L.S. Hollister and M.L. Crawford, Mineralogical Association of Canada, Short Course 6, pp. 209-240.

SWANSON, E.A., STRONG, D.F., and THURLOW, J.G., editors. 1981. The Buchans Orebodies: Fifty Years of Geology and Mining. Geological Association of Canada, Special Paper 22, 350 
p.

SWINDEN, H.S. 1988. Geology and mineral deposits of the southem part of the Robert's Arm Group, including the Gullbridge and Lake Bond deposits. In The Volcanogenic Sulphide Districts of Central Newfoundland. Edited by H.S. Swinden and B.F. Kean. Geological Association of Canada, Mineral Deposits Division, pp. 96-109.

SWINDEN, H.S. and KEAN, B.F. 1984. Volcanogenic sulphide mineralization in the Newfoundland Central Mobile Belt. In Mineral Deposits of Newfoundland - A 1984 Perspective. Newfoundland Department of Mines and Energy, Mineral Development Division, Report 84-3, pp. 55-77.

SWINDEN, H.S. and SACKS, P.E. 1986. Stratigraphy and economic geology of the southern part of the Roberts Arm Group, central Newfoundland. In Current Research, Geological Survey of Canada, Paper 86-1A, pp. 213-220.

SWINDEN, H.S. and THORPE, R.I. 1984. Variations in style of volcanism and massive sulfide deposition in Early to Middle Ordovician Island arc sequences of the Newfoundland Central Mobile Belt. Economic Geology, 79, pp. 1596-1619.

SWINDEN, H.S., KEAN, B.F., and DUNNING, G.R. 1988. Geological and paleotectonic settings of volcanogenic sulphide mineralization in Central Newfoundland. In The Volcanogenic Sulphide Districts of Central Newfoundland. Edited by H.S. Swinden and B.F. Kean. Geological Association of Canada, Mineral Deposits Division, pp. 5-26.

TUACH, J. 1986. Metallogeny of Newfoundland granites-studies in the western White Bay area and on the southwest coast. In Current Research, Newfoundland Department of Mines and Energy, Mineral Development Division, Report 86-1, pp. 27-38.

1987. Mineralized environments, metallogenesis, and the Doucers Valley Fault Complex, western White Bay: a philosophy for gold exploration in Newfoundland. In Current Research, Newfoundland Department of Mines and Energy, Mineral Devel- opment Division, Report 87-1, pp. 129-144.

. 1988a. Geology and volcanogenic sulphide mineralization in the Robert's Arm Group on Pilley's Island, Central Newfoundland. In The Volcanogenic Sulphide Districts of Central Newfoundland. Edited by H.S. Swinden and B.F. Kean. Geological Association of Canada, Mineral Deposits Division, pp. 117-121.

. 1988b. Geology and sulphide mineralization in the Pacquet Harbour Group. In The Volcanogenic Sulphide Districts of Central Newfoundland. Edited by H.S. Swinden and B.F. Kean. Geological Association of Canada, Mineral Deposits Division, pp. 49-53.

TUACH, J. and FRENCH, V.A. 1986. Gold mineralization of possible late Precambrian age in the Jackson's Arm area (12H/15), White Bay, Newfoundland. In Current Research, Newfoundland Department of Mines and Energy, Mineral Development Division, Report 86-1, pp. 39-49.

TUACH, J. and KENNEDY, M.J. 1978. The geologic setting of the Ming and other sulfide deposits, Consolidated Rambler Mines, northeast Newfoundland. Economic Geology, 73, pp. 192-206.

TUACH, J., DEAN, P.L., SWINDEN, H.S., O'DRISCOLL, C.F., KEAN, B.F., and EVANS, D.T.W. 1988. Gold mineralization in Newfoundland: A 1988 review. In Current Research, Newfoundland Department of Mines, Mineral Development Division, Report 88-1, pp. 279-306.

UPADHYAY, H.D. 1970. The geology of the Gullbridge copper deposit, central Newfoundland. Unpublished M.Sc. thesis, Memorial University of Newfoundland, St. John's, Newfoundland, 134p.

UPADHYAY, H.D. and SMITHERINGALE, W.G. 1972. Geology of the Gullbridge copper deposit, Newfoundland: volcanogenic sulphides in cordierite-anthophyllite rocks. Canadian Journal of Earth Sciences, 9, pp. 1061-1073.

WILTON, D.H.C. and STRONG, D.F. 1986. Granite-related gold mineralization in the Cape Ray Fault Zone of southwestern Newfoundland. Economic Geology, 81, pp. 281-295. 